\title{
Global Outlook for 2018: Economy, Finance, and Monetary, with a Particular Case Study of Taiwan
}

\author{
Shyi-Min $\mathrm{Lu}^{1}$ \\ 1 Retired Researcher, Energy and Environmental Laboratories, Industrial Technology Research Institute, \\ Chutung, Hsinchu Taiwan, ROC \\ Correspondence: Shyi-Min Lu, 11F-1, No. 58, Sec. 5, Nanking East Road, Taipei 10597, Taiwan, ROC. Tel: \\ 886-910-354-790. E-mail: shyimin@gmail.com
}

Received: January 23, 2018

Accepted: February 12, $2018 \quad$ Online Published: February 20, 2018

doi:10.5539/ijef.v10n3p133

URL: https://doi.org/10.5539/ijef.v10n3p133

\begin{abstract}
In October 2017, IMF President Christine Lagarde declared that the GDP growth of world's economies in the first half of 2017 was up to the broadest recovery since 2010. So far, the strength of global economic growth has been enhancing. The interest rates and inflation are still at a low level. The global economy has risen from the bottom in 2016 to reach its peak since 2011. As for the degree of economic development, the emerging markets grew fastest, followed by the developing countries, while the advanced economies grew moderately at an average rate around 2\%. Manufacturing PMI in major countries, such as the United States, China, the Eurozone, and even Taiwan, have increased above 50 notably in the recent years, while the non-manufacturing PMI is also above 50. Accordingly, the main purpose of this paper is to forecast the global economy in 2018, which is on the trajectory of booming with a certain degree of uncertainty. A particular case study of Taiwan's overall economic development is presented as well.
\end{abstract}

Keywords: world, Taiwan, economy, finance, currency

\section{Introduction}

In 2017, thanks to the simultaneous recovery of major economies, like the rebound in international trade momentum, the corporate profits improvement, the currencies easing, the fiscal policies expansion etc., the momentums of funds are abundant, the global financial markets are trading hotly, the general upward trend has emerged, and the major countries' stocks all hit record highs. However, with the gradual normalization of the U.S. currency entering into an interest rate rise cycle, it will affect the decisions of many central banks.

Looking forward to 2018, the global monetary policy and the overall financial market environment are still full of uncertainties. It is expected that in the future, the direction of major countries' monetary policy will be moderately tightened. How the global fund parties to end up and how the adjustment of the asset prices to affect the global financial markets in 2018 are the most crucial uncertainties in the future. In addition, in May 2017, the Taiwanese stock market (TAIEX) broke through 10,000 points mark for the fifth time in the history by setting a record high in 27 years. The duration of over 10,000-point so far is the longest one in Taiwanese stock history.

Facing the record high and many uncertain factors, the emotional reaction of investors is sensitive particularly in interpreting and mastering a large number of daily financial news. How to analyze the messages and translate them into specific operational strategies and investment layout is a key point to become a winner in this hike wave of stock market, especially for the general public who are concerned about the financial investment.

\section{The Global Economic Review and Forecast}

In last year (2017), the global economy entered a rising cycle, getting rid of the haze of stagnant growth since 2012. Benefiting from the leading economic recovery in advanced countries, the real economic momentum of global investment, trade and industrial production is boosting. The business and consumer markets regain their confidence. The financial markets are inter-trading enthusiastically. Nearly $75 \%$ of the world's economies are growth-accelerating simultaneously. Their economic growth outperforms the original expectation. In this year (2018), with the continuous improvement in the growths of emerging markets and developing countries, the global economic recovery is expected to further expand. In the short term, the global economy will continue to grow. 
IHS Markit forecasts that the global economic growth rate will be $3.2 \%$ in 2018, roughly same as 2017 , significantly up from $2.5 \%$ in 2016, reaching the highest level since 2012. The developed countries have a forecasted economic growth rate about $2.3 \%$ in 2018, roughly same as that of 2017. The developing countries' economic growth rate will be $3.6 \%$ in 2018 , increasing $0.2 \%$ over the previous year (2017). The emerging countries enjoy the strongest growth with a growth rate of about $4.8 \%$ (Table 1). The economic performances of all the major economies in 2017 and 2018 are as follows.

(1) In the United States, the economic growth increases from $1.5 \%$ in 2016 to $2.3 \%$ in 2017 and further to $2.6 \%$ in 2018;

(2) In the EU (excluding Britain), the economic growth increases from 1.9\% in 2016 to $2.6 \%$ in 2017, and slows to $2.3 \%$ in 2018 ;

(3) In Mainland China, the economic growth slightly increases from $6.7 \%$ in 2016 to $6.8 \%$ in 2017 and slows to $6.5 \%$ in 2018 ;

(4) In Japan, the economic growth is $1.8 \%$ in 2017, the highest one since 2005 and downs to $1.2 \%$ in 2018.

Table 1. Global economic growth rates and customs export growth rates forecasted by IHS Markit (unit: \%)

\begin{tabular}{lcccc}
\hline Economic growth rate (\%) & 2015 & 2016 & 2017 & 2018 \\
\hline World & 2.9 & 2.5 & 3.2 & 3.2 \\
Developed countries & 2.3 & 1.6 & 2.3 & 2.3 \\
Developing countries & 1.2 & 3.9 & 3.4 & 3.6 \\
Emerging markets & 4.1 & 3.9 & 4.8 & 4.8 \\
\hline Customs export growth rate (\%) & 2015 & 2016 & 2017 & 2018 \\
\hline World & -12.9 & -2.9 & 10.3 & 6.9 \\
Developed countries & -10.9 & -1.4 & 8.9 & 5.9 \\
Developing countries & -26.7 & -4.0 & 10.7 & 6.2 \\
Emerging markets & -14.5 & -5.1 & 12.6 & 8.4 \\
\hline
\end{tabular}

Source: IHS Markit (2017a).

According to the IHS Markit statistics and forecasts, with the exception of the United States, for the major economies of the world, the economic growth in 2017 all increase over 2016 but slightly lower than 2018, such as Japan, Eurozone, South Korea, Singapore, Taiwan, China and so on. Taiwan's economic growth rate in 2018 is estimated to be $2.41 \%$, slightly down about $0.3 \%$ from $2.54 \%$ in 2017 . See Table 1 .

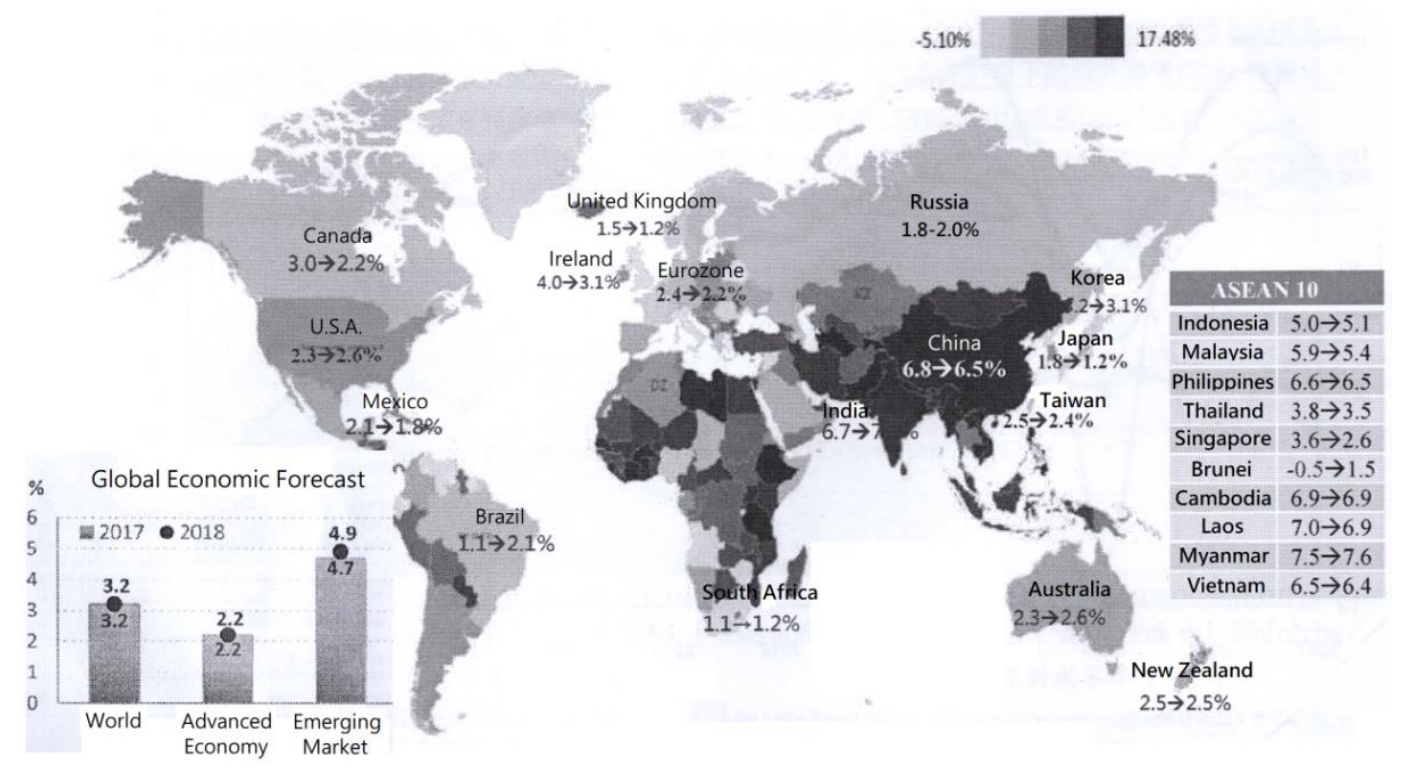

Figure 1. Major countries' economic growth rates (2017 -> 2018)

Source: IHS Markit (2017b). 


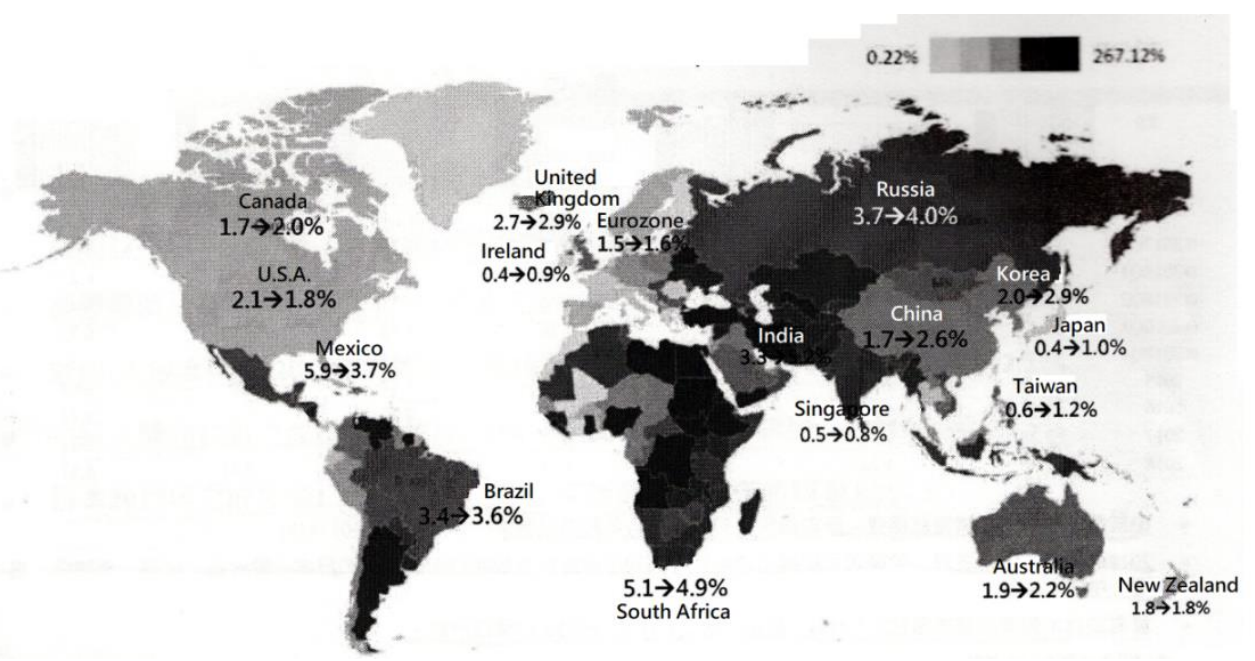

Figure 2. Major countries' inflation rates for 2017 -> 2018 (CPI yearly rate)

Source: IHS Markit (2017a).

IHS also forecasts that the global annual growth rate of CPI (Consumer Price Index) in 2018 will fall $0.1 \%$ from 2017 to 3.0\%. The CPI growth rate of developed countries in 2018 will be the same as that in 2017 (i.e., 1.7\%) and that of emerging market countries in 2018 will down from $4.9 \%$ to $4.8 \%$, as shown in Figure 2.

\section{The Global Overall Economic Environment}

\subsection{The Global Economic and Climate Indicators Hit a New High}

Refer to Figure 3. According to WES data, in 2017Q4, the global economic and climatic indicators hit a new high since 2011Q2. The overall development remains positive and optimistic to maintain recovery trajectory. Notably, the economic status is assessed at 17.2 points, with an increase of six consecutive quarters in a row, meaning a further enhancement of the confidence of recovery. The economic outlook for the future is at 16.9 points, which is still optimistic. Refer to Table 2. Judging from the relevant economic sentiment indicators in recent years, such as the economic prosperity, the current status and the future development trend, the economy has been gradually and steadily recovering. A steady growth of economy in the coming year is for sure.

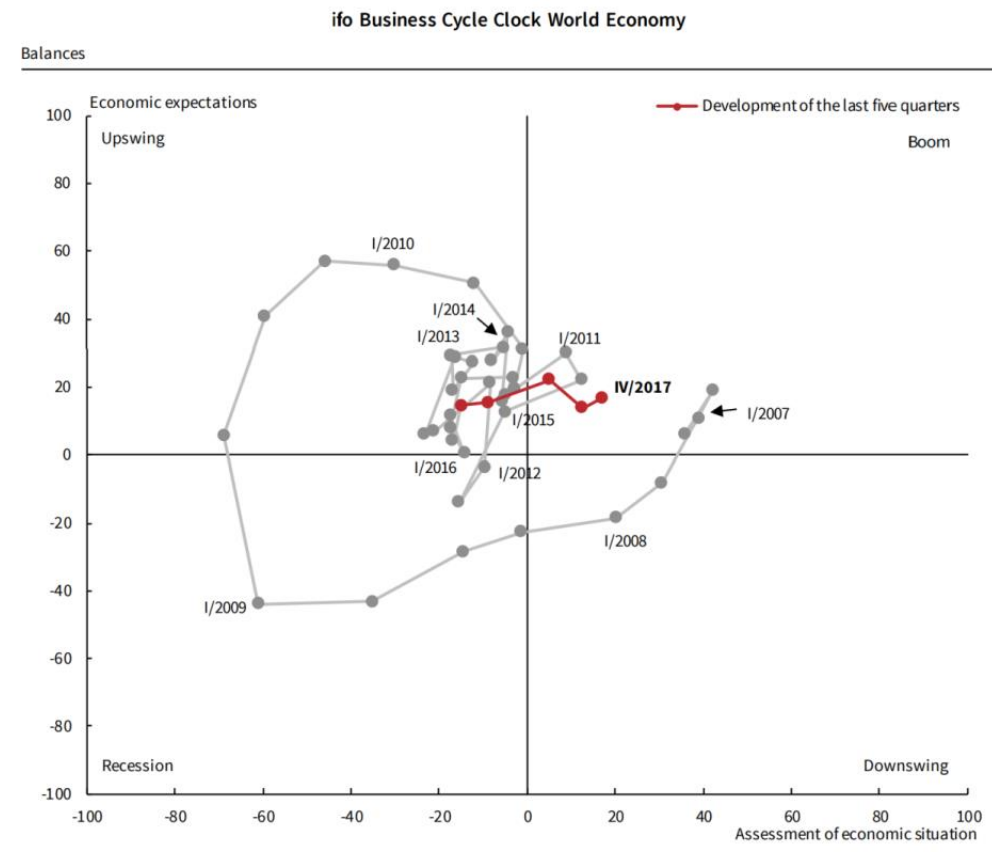

Figure 3. ifo world economy cycle clock 
Table 2. Global economic and climate indicators in last three years

\begin{tabular}{lccccccccc}
\hline & IV/2015 & I/2016 & II/2016 & III/2016 & IV/2016 & I/2017 & II/2017 & III/2017 & IV/2017 \\
\hline Economic climate & -5.1 & $-7.0 \downarrow$ & $-3.5 \uparrow$ & $-6.6 \downarrow$ & $-0.7 \uparrow$ & $3.0 \uparrow$ & $13.5 \uparrow$ & $13.2 \downarrow$ & $17.1 \uparrow$ \\
Current status & -17.6 & $-14.2 \uparrow$ & $-17.4 \downarrow$ & $-16.8 \uparrow$ & $-14.9 \uparrow$ & $-8.7 \uparrow$ & $5.1 \uparrow$ & $12.5 \uparrow$ & $17.2 \uparrow$ \\
Future outlook & 8.2 & $0.5 \downarrow$ & $11.6 \uparrow$ & $4.1 \downarrow$ & $14.6 \uparrow$ & $15.5 \uparrow$ & $22.2 \uparrow$ & $14.0 \downarrow$ & $16.9 \uparrow$ \\
\hline
\end{tabular}

Source: ifo (2017).

\subsection{The Global Economy Has Obviously Risen}

According to the ifo global economic cycle clock (Figure 3), the global economy, led mainly by the advanced countries (including G7 and the Eurozone), has entered the prosperity quadrant, followed by the recoveries of the emerging markets and developing countries, now moving toward the prosperity quadrant, expected to continue to grow, thus expanding the foundation of future global recovery.

In 2017, the global economy had been recovering at the same pace. More than $75 \%$ of economies simultaneously were accelerating their growth. It is expected that GDP (Gross Domestic Product) will be at a new high in next years. Major international forecast institutions have upwardly revised their original GDP forecasts. It means that the economic trends will continue to rise in the short-term.

As the global trade continues to heat up, the WTO (World Trade Organization) said that their trade volume growth rate is 1.3 times of the economic growth rate in 2017. However, the global trade growth momentum will decline slightly in 2018. See Table 3.

Table 3. Global economic and trade growth rates forecasted by the major financial and economic institutions for 2017-18

\begin{tabular}{lccccc}
\hline & \multirow{2}{*}{ Forecast date } & \multicolumn{2}{c}{ Global GDP } & \multicolumn{2}{c}{ Global trade } \\
\cline { 3 - 6 } & & 2017 & 2018 & 2017 & 2018 \\
\hline IHS & $2017 / 11$ & 3.2 & 3.2 & - & - \\
OECD & $2017 / 11$ & 3.6 & 3.7 & 4.75 & 4.11 \\
IMF & $2017 / 10$ & 3.6 & 3.7 & 4.20 & 4.00 \\
WTO & $2017 / 9$ & - & - & 3.60 & 3.20 \\
WB & $2017 / 6$ & 2.7 & 2.9 & 4.00 & 3.80 \\
UN & $2017 / 12$ & 3.0 & 3.0 & 3.70 & 3.50 \\
EIU & $2017 / 12$ & 3.7 & 3.6 & 4.60 & 3.50 \\
\hline
\end{tabular}

Source: $\mathrm{Wu}(2017)$.

\subsection{Continuous Growth in the Next Two Years}

According to OECD Economic Outlook (Figure 4), the growth of major countries in the next two years (2018-2019) will be still below the pre-financial crisis (2007-2008) levels. The average economic growth rate of OECD countries is about $2.2 \%$, that of non-OECD countries is $4.8 \%$, and the global growth momentum maintains a level of $3.7 \%$. Among them, China and India that have always had outstanding performances will remain at $6.5-7 \%$. About 30 countries of the OECD's 45 major countries predict "steady growth" and another 15 for "accelerating growth".

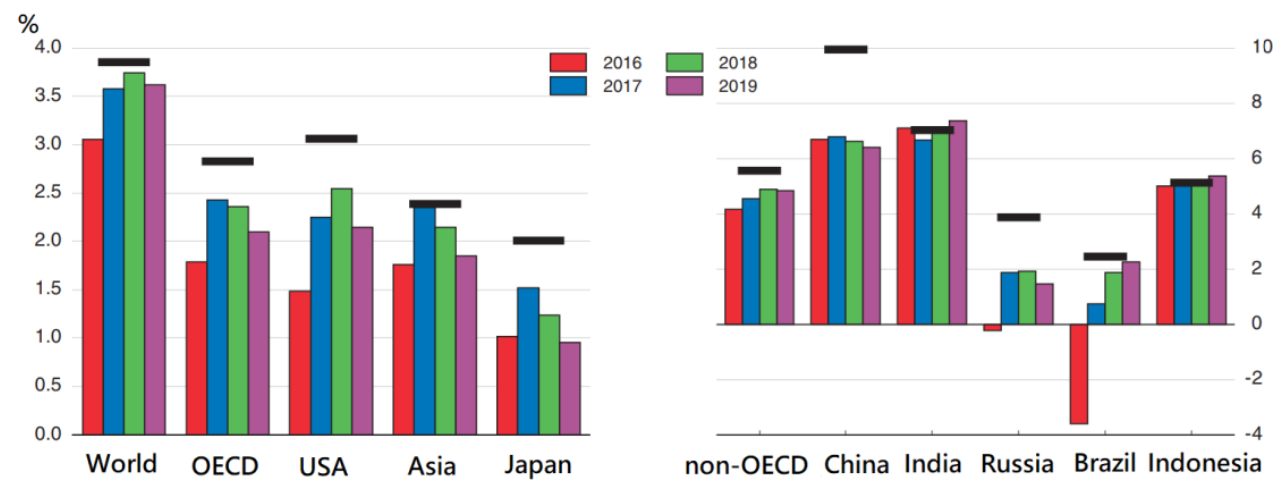

Figure 4. Economic growths in globe and major countries in recent years - the real GDP (\%)

Source: OECD (2017). 
However, what worries us is that 19 countries in the same 45 major OECD countries predicted "steady growth" and as many as 36 countries predicted "accelerating growth", on the base of the historical data in 2007 (Figure 5). Although this optimistic economic prediction, the financial crisis that broke out in the following year (2008) shocked the world.

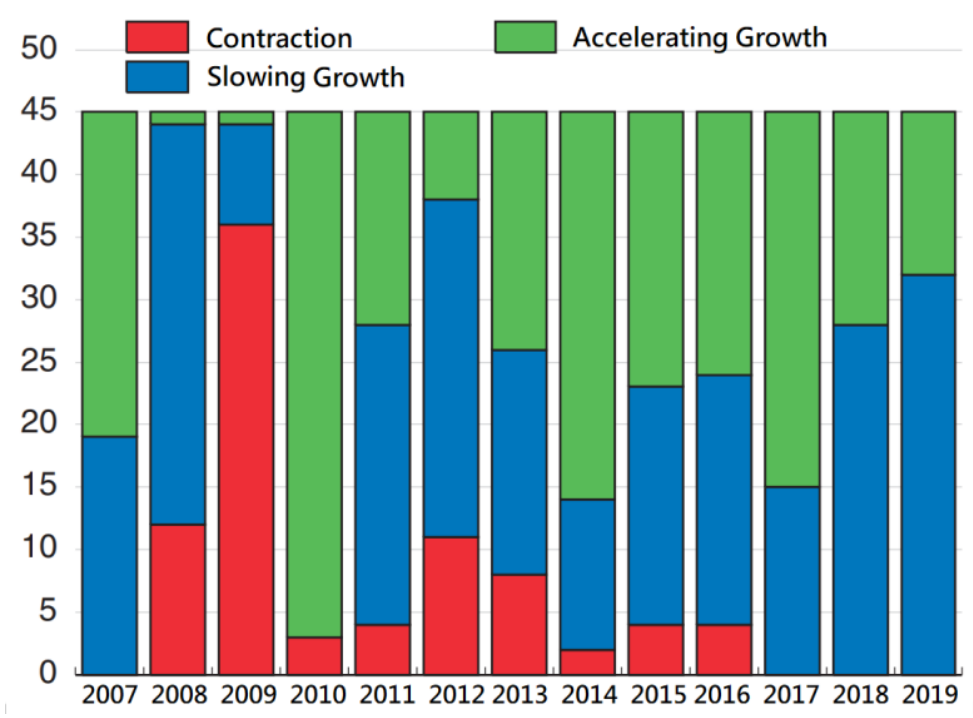

Figure 5. OECD growth forecast for 45 major countries in the world

Source: OECD (2017).

\subsection{Economic Momentum Indicators}

According to IMF data (Figure 6), the global industrial production growth remains high. In 2017, the PMI (Purchasing Managers' Index) approaching 55 hit a new high for recent years, indicating a notable enthusiasm of global economic production. Meanwhile, the manufacturing PMI in the advanced countries set a new record of 56 since 2012, while the PMIs in emerging markets also surpass 50, on the path of expansion.

Global consumer confidence, still dominated by the advanced countries, is optimistic. However, the consumer confidence index in the emerging markets has failed to exceed 100 (based on 2010) for a long period of time, with a trend towards pessimism. As shown in Figure 6, the major global manufacturing PMIs are all greater than 50 and the non-manufacturing PMIs are above 50 as well.
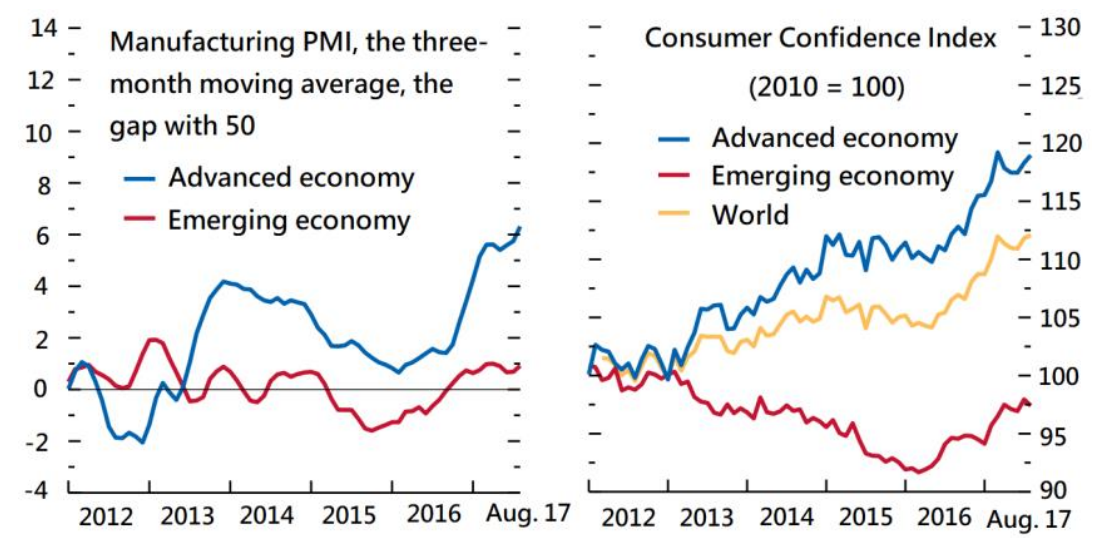

Figure 6. All-economic momentum indicator trends - manufacturing PMI and consumer confidence index Source: IMF (2017).

\subsection{Staple Merchandise Prices and Inflation}

International oil prices dropped in the first half of 2017, easing the overall consumer price inflation. As the oil prices rose in the second half of the year, the domestic demand expanded and the unemployment rate declined. 
The core inflation responded in the advanced economies were higher than those of the emerging markets and developing economies. See Figure 7.

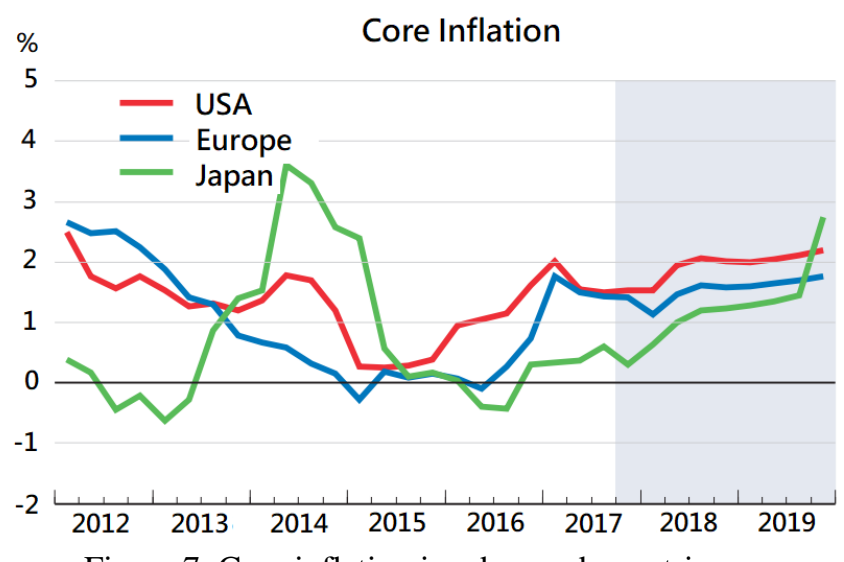

Figure 7. Core inflation in advanced countries

Source: OECD (2017).

\subsection{The International Crude Oil Prices Forecast}

According to the forecasts of international banks and analysts, the average Brent crude oil price in 2018 is 58.84 US dollars/barrel, with a forecast range between 49.33-70 US dollars/barrel. The latest international crude oil price of Brent is 67.72 US dollars/barrel (2018.1.5), setting a new high in 2.5 years. The observation points for oil price hike are the Israel-Palestine crisis, the political turmoil in Saudi Arabia, the oil production cuts by Libya and Nigeria, the economic recession in Venezuela and other geopolitical tensions. On the other hand, the watch-points for oil price decline are Russia to expand the production in the new oilfields and the boost of crude oil export capacity stimulated by the increase of shale oil production in the United States. See Figure 8.

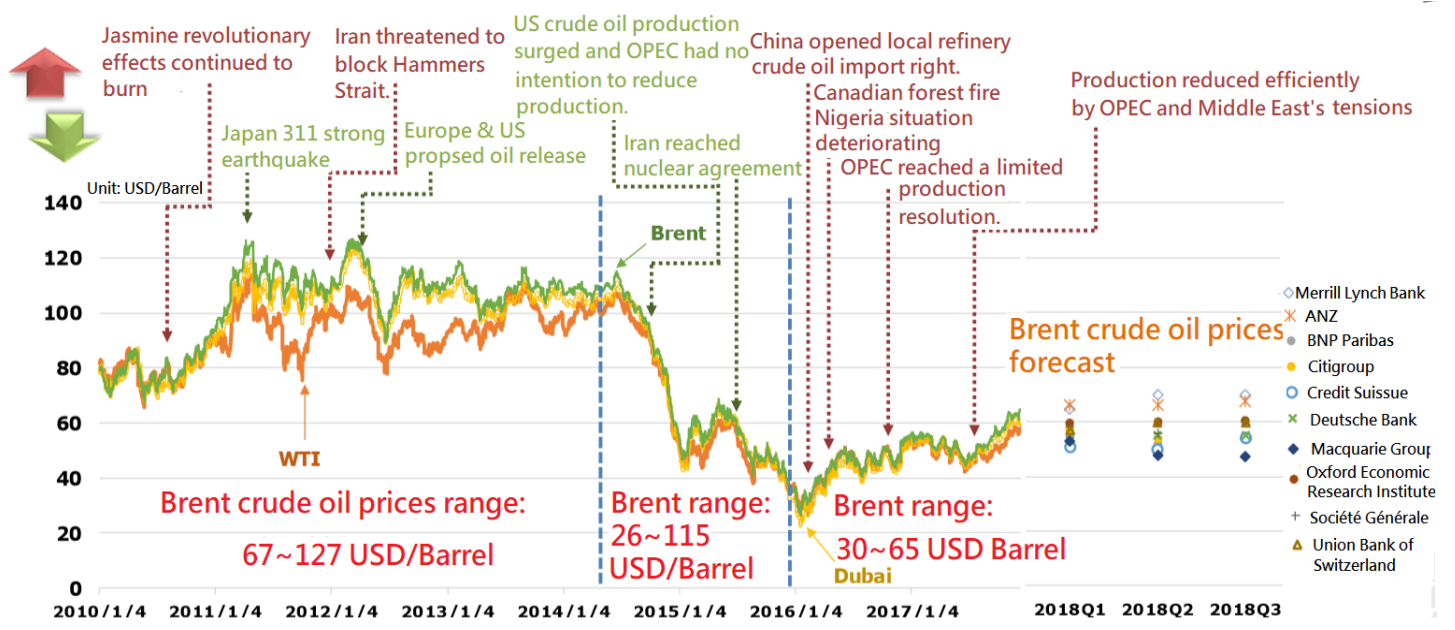

Figure 8. Historical events and future trend outlook for Brent crude oil price

Source: Taiwan Research Institute (2017); Union Bank of Switzerland.

\subsection{Real Effective Exchange Rate}

In the first half of 2017, in addition to the Euro, the real effective exchange rates of major countries tended to devalue. The trends of Taiwan and South Korea were similar. However, the trends reversed in the second half year. As of November 2017, the upward trend of the Taiwan dollar has been greater than that of the Korean Won. In other words, for the past six months, the devaluation of the Taiwan dollar has been less than the Korean Won, thus that the gap between the Taiwan dollar and the Korean Won had narrowed.

\subsection{The Growth Multiples of the OECD Countries' Consumption, Investment and Trade}

The OECD countries witnessed a sharp decline in their investment and trade growth in 2016, reaching a record low in recent years. Relatively smooth private final consumption has maintained a steady relationship with the 
economic growth (with a ratio around 1:1). However, the investment and trade growths in recent years are both above the economic growth, while the trade growth multiple is below the long-term average.

\subsection{The Global Trade Outlook}

World Trade Outlook Index (WTOI) is 102.2 for 2017Q2, which is a turning point in the growth momentum of global trade and trend observed by the World Trade Outlook. The leading indicators are above the trend. The short-term global export trade is still showing upward momentum. Among the indicators, the export orders, the international air transport volume, the container port throughput and the electronic components are all above 100. The electronic components trade is better than previous quarter. Although the trade in agricultural raw materials is below the trend, it still grows from the previous quarter. In sum, the short-term global trade still maintains an upward trend. Refer to Figure 9 and Table 4.

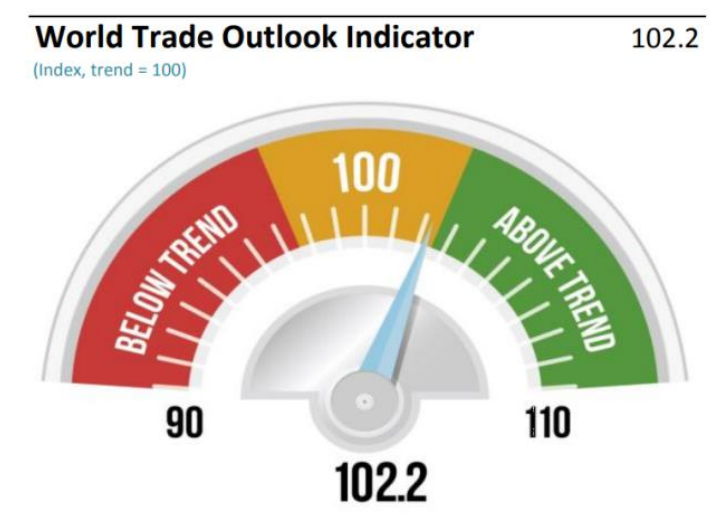

\begin{tabular}{lccc} 
Drivers of trade & $\begin{array}{c}\text { Level of } \\
\text { Index }\end{array}$ & $\begin{array}{c}\text { Direction } \\
\text { of change }\end{array}$ \\
\hline Merchandise trade volume (Q2) & 102.2 & \\
\hline Export orders & 101.9 & \\
\hline International air freight (IATA) & 106.7 & \\
\hline Container port throughput & 102.3 & \\
\hline Automobile production and sales & 96.3 & $\checkmark$ \\
\hline Electronic components & 103.3 & \\
\hline Agricultural raw materials & 97.1 & \\
\hline
\end{tabular}

Figure 9. Global trade outlook

Source: WTO (2018).

Table 4. Changes in WTOI and component indices

(Point changes in index values)

\begin{tabular}{|c|c|c|c|c|}
\hline & \multicolumn{3}{|c|}{ Month-on-month change } & \multirow[t]{2}{*}{ Year-on-year change } \\
\hline & \multicolumn{3}{|c|}{2017} & \\
\hline & July & August & September & September \\
\hline WTOI & 0.2 & 0.1 & 0.0 & 2.5 \\
\hline Export orders & -0.1 & -0.2 & -0.2 & 2.7 \\
\hline Air freight & 0.5 & 0.3 & -0.1 & 7.0 \\
\hline Container shipping & 0.0 & -0.1 & -0.1 & 4.0 \\
\hline Automobiles & -0.2 & -0.1 & -0.2 & -6.9 \\
\hline Electronics & 1.1 & 0.5 & 0.2 & 4.5 \\
\hline Raw materials & 0.7 & 0.9 & 1.0 & -4.8 \\
\hline
\end{tabular}

Source: WTO (2018).

\section{Economic Outlook for Major Economies for 2018 by Looking Back 2017}

\subsection{The United States}

\subsubsection{Into Monetary Double Tight Phase with Bright Economic Data}

Recently, a number of indicators of the United States responses the steady economic recovery. In November 2017, the PCE (Personal Consumption Expenditures) price index rose 1.6\% y/y, fell short of the Fed's target of $2 \%$. The unemployment rate of $4.1 \%$ was the lowest in 17 years, near full employment, becoming a strong support for raising interest rates. It is expected that the Fed will raise interest rates again in 2018 and shrink balance sheet as scheduled. Monetary policy of the United States has officially entered a dual phase of "raising interest rates as well as shrinking balance sheet".

4.1.2 Impacted by the Tax Reform and the Interest Rate Rise, the US Stock/Exchange Markets to Strengthen Continuously

Affected by the Fed's interest rate rise and Trump's tax reform, the stock/exchange markets of the United States 
strengthen simultaneously, but are still in turmoil under the influence of uncertainty in the short term. The U.S. bond yields continue to flatten. The bond yield difference between two-year and 10-year has dropped to 50 basis points, setting a new lowest in 10 years. It is estimated that the yield curve will be inverted in 2018. The U.S. stock indices are strongly supported by the bullish news, hitting record high.

\subsubsection{The United States' Recent Economic Growth Is Better than the Expected and Strong}

In the third quarter of 2017, the real GDP growth rate of the United States was 3.3\%, the highest quarterly growth rate since 2014, maintaining above 3\% in a row of two quarters. The major momentums came from the commercial investment, the exports, and the inventories, in which the commercial investment was up $7.3 \%$, the highest since 2016. Refer to Table 5.

Table 5. Economic indicators of the United States in September-October 2017

\begin{tabular}{|c|c|c|}
\hline US economic indicator & October 2017 & September 2017 \\
\hline Newly added non-agricultural population & 261,000 & $-33,000$ \\
\hline Unemployment rate & $4.10 \%$ & $4.20 \%$ \\
\hline Labor rate & $62.7 \%$ & $63.1 \%$ \\
\hline Wage growth rate (hourly/monthly) & $0 \%$ & $0.5 \%$ \\
\hline Wage growth rate (yearly) & $2.43 \%$ & $2.87 \%$ \\
\hline U.S. price index & Monthly increase & Yearly increase \\
\hline CPI (October/September)* & $0.1 \% / 0.55 \%$ & $2 \% / 2.2 \%$ \\
\hline Core CPI (October/September)* & $0.2 \% / 0.13 \%$ & $1.8 \% / 1.7 \%$ \\
\hline PCE, Price index (October) ${ }^{@}$ & $0.1 \%$ & $1.6 \%$ \\
\hline PCE, Price index $(\text { October })^{@}$ & $0.2 \%$ & $1.4 \%$ \\
\hline Industrial production (October) ${ }^{\#}$ & $0.95 \%$ & $1.67 \%$ \\
\hline
\end{tabular}

Note. *: October CPI annual growth rate $2 \%$, down from $2.2 \%$ in September, the first decline since June. However, the core CPI hit the highest level since April, with the major increases coming from transportation services ( $4.2 \% \mathrm{y} / \mathrm{y})$ and housing $(3.2 \% \mathrm{y} / \mathrm{y})$.

@: PCE annual growth rate 1.6\% higher than market expectations $1.5 \%$.

\#: The index of industrial production hit its biggest gain in six months, hurricane intervention ebbed.

Source: Bureau of Labor Statistics (2017).

4.1.4 In Recent Years, the PMI of the ISM (Institute for Supply Management) Shows That the United States' Economy Looks Strong in 2018

From ISM's US PMIs of 2000-2017, it shows that the United States' economy is strong for 2018. In addition, there is a great chance of the dollar appreciation in the first half of 2018, with the forecast that the US Dollar Index (DXY) will be between 92.5 and 97. In November 2017, Federal Open Market Committee (FOMC) estimated that the economic recovery in the United States had been very robust. The corporate capital expenditures took off, compared with the previous one. A corporate tax of $20 \%$ and the overseas profit repatriation tax of $10 \%$ result that the US corporate tax falls to the lowest from the third highest in 188 countries. With import substitution measures and infrastructure expansion in the future, FDI (Foreign Direct Investment) funds are attracted to flow into the United States, leading a rise of the U.S. dollar. In addition, the Fed's "shrinking the balance sheet" also creates a dollar appreciation, but tax cuts and public spending expansion will result in substantial debt, pushing up the long-term bond rates, raising the market interest rates, making the hot money spreads to arbitrage and the portfolio funds in other countries flowing into the United States, further pushing up the dollar. However, from the United States own experience and the economic theory, the Fed's interest rate rise due to inflation (hawk) will devalue the dollar. Moreover, a strong dollar will lead to massive imports, equivalent to lose employment opportunities and increase trade protectionism. If the United States imposed trade sanctions to force the currency of its trading partners to appreciate, the dollar would devalue substantially.

\subsection{Europe}

\subsubsection{Eurozone Service/Manufacturing PMI to Indicate a Full Recovery in Europe}

Eurozone services/manufacturing PMI shows that Europe is recovering fully. In October 2017, EU decided to reduce QE 50\% to 30 billion euros, so the euro is substantially supported (Table 6). 
Table 6. Eurozone services/manufacturing PMI

\begin{tabular}{lcccccc}
\hline & $2017 / 6$ & $2017 / 7$ & $2017 / 8$ & $2017 / 9$ & $2017 / 10$ & $2017 / 11$ \\
\hline Eurozone & 55.4 & 55.4 & 54.7 & 55.8 & 55.0 & 56.2 \\
Germany & 54.0 & 53.1 & 53.5 & 55.6 & 54.7 & 54.3 \\
France & 56.9 & 56.0 & 54.9 & 57.0 & 57.3 & 60.4 \\
Italy & 53.6 & 56.3 & 55.1 & 53.2 & 52.1 & 54.7 \\
Spain & 58.3 & 57.6 & 56.0 & 56.7 & 54.6 & 54.4 \\
\hline
\end{tabular}

Source: Markit Economics (2017).

\subsubsection{European Economy to Accelerate Growth in a Policy-Changing Environment}

In the latest economic forecast report for 2017, the European Commission pointed out that the Eurozone economy would meet the fastest growth in 10 years. The Eurozone was predicted a substantial increase in GDP growth to $2.2 \%$, while that of the EU was expected to reach $2.3 \%$; and, that of the United Kingdom trapped in Brexit then downed to $1.5 \%$. The economic growth in Europe is mainly contributed by the strong growth of private consumption and investment. Although the labor market in the Eurozone has performed exceptionally well, the wage growth is still slow, and the core inflation is too weak to meet the ECB (European Central Bank) target of $2 \%$. Refer to Table 7.

Table 7. European economic growth (\%)

\begin{tabular}{lccc}
\hline & 2017 & 2018 & 2019 \\
\hline Eurozone & 2.2 & 2.1 & 1.9 \\
European Union & 2.3 & 2.1 & 1.9 \\
United Kingdom & 1.5 & 1.3 & 1.1 \\
\hline
\end{tabular}

Source: European Commission (2017).

\subsection{Debt-Driven Investment in Mainland China}

OCED estimates that the GDP growth in Mainland China will be $6.7 \%$ in 2017 and will slow down in the next two years. However, the economic growth of Mainland China still plays a critical role in global market. Although the foreign exchange reserves in Mainland China have picked up gradually, the implementation of the tax reform of the United States will put pressure on Mainland China, such as the flowing out of capital, the devaluation of RMB, and the reform of domestic tax system.

The IMF points out that the economic strategy of over-reliance on credit of Mainland China may lead to huge debts. At present, the debt in Mainland China has reached a dangerous level, which is likely to trigger the next global financial crisis.

\subsection{A Magnificent Year for Taiwan}

On January 22, 2018, Statistics Department of the Ministry of Economic Affairs (MOEA) announces that the export orders amount of last month is 48.47 billion US dollars, an increase of $17.5 \%(\mathrm{~m} / \mathrm{m})$, which is a positive growth in 17 consecutive months. In entire 2017, the export orders amount is 492.81 billion US dollars, hitting a record high. Looking forward to 2018, MOEA believes that the economic growth will rise moderately, while the export orders should grow slightly.

On the same day, the Statistics Office of Executive Yuan announces that the unemployment rate in last month is $3.66 \%$, down $0.05 \%$ and the annual unemployment rate is $3.76 \%$, down $0.16 \%$, which is the lowest level since 2001. Affected by the economic recovery, the job market will be stable throughout the year.

\section{Taiwanese Economy}

\subsection{Taiwanese Economic Problems}

\subsubsection{The Economic Composition and Trend of Growth}

In Taiwan, from 2002 to 2007, the private final consumption growth dropped sharply. The investment activity flourished in the 1990s, with an investment growth multiple of 1.4. However, the investment growth was less than the economic growth after 2000. From 2012 to 2016, Taiwan's import and export witnessed a sharp decline. The economic growth was slackened and the international trade growth multiple was below 2, even lower than the global average. Refer to Table 8 . 
Table 8. Economic growth of Taiwan in the past (1980-2016)

\begin{tabular}{lcccccccc}
\hline & \multicolumn{2}{c}{$1980 \mathrm{~s}$} & \multicolumn{2}{c}{$1990 \mathrm{~s}$} & \multicolumn{2}{c}{ 2002-2007 } & \multicolumn{2}{c}{$2012-2016$} \\
\cline { 2 - 9 } & $\begin{array}{c}\text { Growth } \\
\text { rate }(\%)\end{array}$ & $\begin{array}{c}\text { Growth } \\
\text { multiple }\end{array}$ & $\begin{array}{c}\text { Growth } \\
\text { rate }(\%)\end{array}$ & $\begin{array}{c}\text { Growth } \\
\text { multiple }\end{array}$ & $\begin{array}{c}\text { Growth } \\
\text { rate }(\%)\end{array}$ & $\begin{array}{c}\text { Growth } \\
\text { multiple }\end{array}$ & $\begin{array}{c}\text { Growth } \\
\text { rate }(\%)\end{array}$ & $\begin{array}{c}\text { Growth } \\
\text { multiple }\end{array}$ \\
\hline Real GDP & 8.53 & & 6.63 & & 5.63 & & 2.10 & \\
Private final consumption & 8.79 & 1.03 & 7.36 & 1.11 & 3.20 & 0.57 & 2.51 & 1.20 \\
Governmental consumption & 7.64 & 0.90 & 5.57 & 0.84 & 0.71 & 0.13 & 1.73 & 0.82 \\
Fixed capital formation & 7.86 & 0.92 & 8.19 & 1.24 & 3.79 & 0.67 & 1.73 & 0.82 \\
Export & 12.13 & 1.42 & 7.56 & 1.14 & 11.14 & 1.98 & 2.27 & 1.08 \\
Import & 11.08 & 1.30 & 8.19 & 1.12 & 7.00 & 1.24 & 2.37 & 1.13 \\
\hline
\end{tabular}

Source: Directorate-general of Budget, Accounting and Statistics, Executive Yuan (Update 2017.11.24).

\subsubsection{WEF-the Top 10 Problems for Doing Business in Taiwan}

Every year, the WEF (World Economic Forum) reports a survey of major issues in the business environment for major countries in the world. For Taiwan, the most serious problem is policy instability that is only slightly improved, compared to the last year. The restrictions by labor laws and regulations, tax rates, government instability, labor education, and inflation have further worsened, as shown in Figure 10.

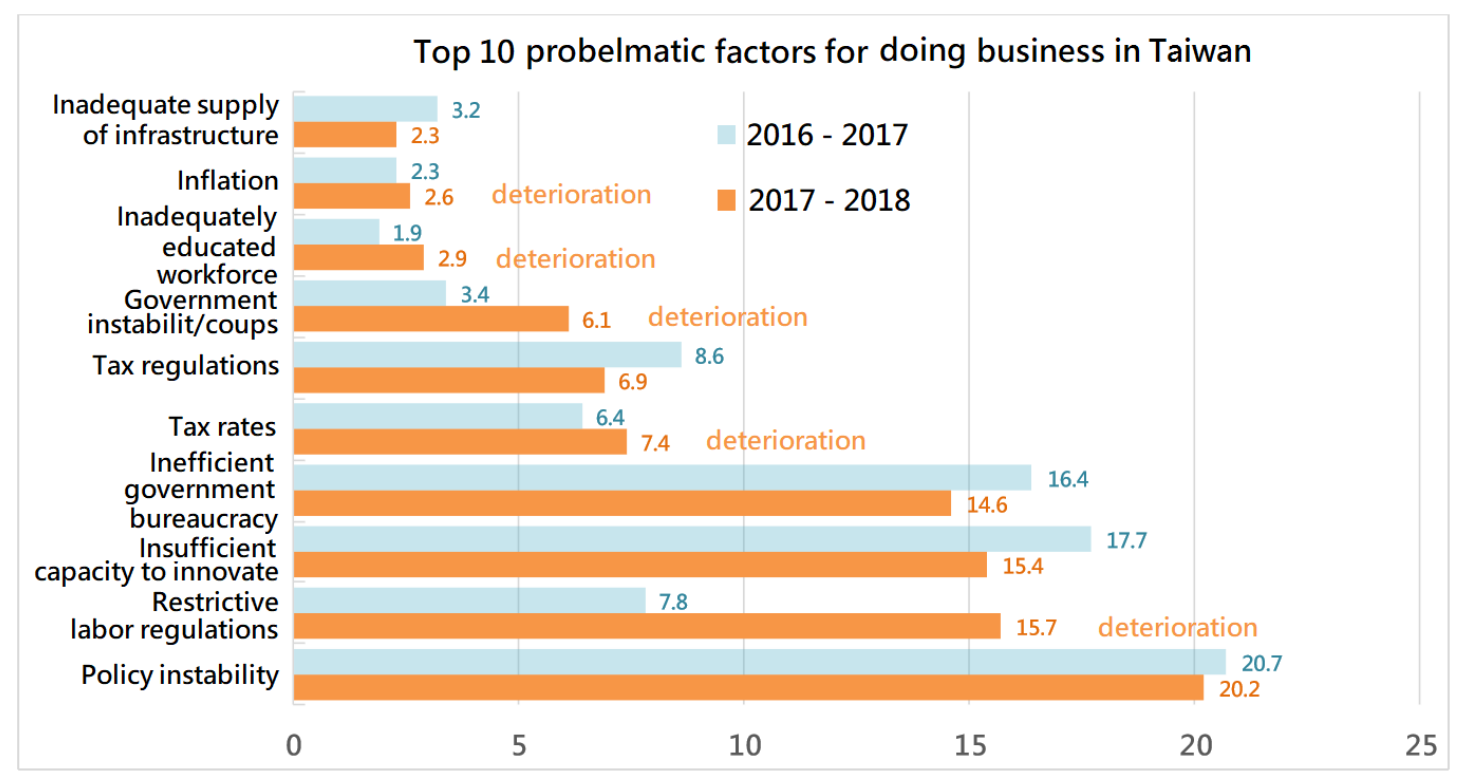

Figure 10. WEF - the top 10 problematic factors for doing business in Taiwan

Source: WEF, The Global Competitiveness Report (2016-2017, 2017-2018 edition).

\subsubsection{Weak Domestic Demand}

The domestic demand market slump in Taiwan has not seen any improvement and the people don't feel the boom recovery either, although the export is robust. Compared with the OECD countries, the contribution rate of private final consumption growth in Taiwan is weak and the fixed capital formation has not enhanced for a long time.

\subsubsection{Low Salary and Big Gap between Poor and Rich}

In recent years, as the average monthly wage in Taiwan has risen, the overall pay distribution has become more and more discrete with polarization. The proportion of low-wage groups accounts for $1 / 4$ of the total, the compositions of which include $82.4 \%$ of those under 20 and $32.6 \%$ of those aged $21-30$. The most serious industries of the low-wage earners are services (50\%), lodging and restaurant (44.8\%). Refer to Table 9. 
Table 9. Average monthly salary difference in Taiwan

\begin{tabular}{llllll}
\hline & 2011 & 2012 & 2013 & 2014 & 2015 \\
\hline Average monthly salary & 44.9 & 45.3 & 44.8 & 46.6 & 47.8 \\
Standard deviation & 55.7 & 53.3 & 52.2 & 60.5 & 61.0 \\
Low-wage threshold & 22.2 & 22.6 & 22.3 & 23.1 & 23.4 \\
Q1 & 21.7 & 22.0 & 22.1 & 22.8 & 23.3 \\
Q3 & 51.7 & 52.3 & 51.5 & 53.5 & 54.5 \\
D1 & 17.2 & 17.7 & 18.3 & 18.9 & 19.2 \\
D9 & 83.4 & 83.6 & 82.3 & 85.8 & 88.3 \\
\hline
\end{tabular}

Unit: thousand NTD.

Source: Statistics Office, Ministry of Finance (2017).

\subsubsection{Low Investment Inclination}

The investment activity of Taiwanese manufacturing industry is heavily dependent on the direct financing means. Financing has not been an obstacle to the decision-making on investment, while the overall investment has dropped. Therefore, the low willingness to invest is not from the impact of financial factors. Therefore, the yearly added fixed assets are beaten by the capital consumption that erodes the existing fixed capital stock. Refer to Table 10 .

Table 10. Taiwanese manufacturing investment data (2003-2007; 2012-2016)

\begin{tabular}{lcccccc}
\hline (Fixed asset purchase/operating surplus) & $2003-2007$ & 2012 & 2013 & 2014 & 2015 & 2016 \\
\hline Manufacturing & 1.13 & 0.90 & 0.78 & 0.62 & 0.58 & 0.62 \\
Electronic component manufacturing & 2.41 & 2.51 & 1.58 & 0.96 & 1.05 & 1.24 \\
Computer, electronic products and optical products & 0.35 & 0.19 & 0.15 & 0.12 & 0.15 & 0.15 \\
Chemical materials manufacturing & 0.62 & 0.79 & 0.74 & 0.95 & 0.33 & 0.26 \\
Machinery and equipment manufacturing & 0.66 & 0.29 & 0.24 & 0.21 & 0.26 & 0.27 \\
Basic metal manufacturing & 0.45 & 0.91 & 0.65 & 0.30 & 0.41 & 0.40 \\
\hline
\end{tabular}

Source: Department of Statistics, Ministry of Economic Affairs (2017); Directorate-general of Budget, Accounting and Statistics, Executive Yuan (Update 2017.11.24).

\subsubsection{Public Sector Plays an Important Role}

Since Taiwanese economy as a whole lacks the investment flowing water, the investment inclination is sluggish. It is expected that the infrastructure investment expansion by the government will play a critical role on boosting the economic growth, when the "Forward-looking Infrastructure Plan" officially launches in 2018.

\subsection{Taiwanese Economic Forecast for 2018}

\subsubsection{Boom Lights}

In October 2017, due to the weakening growths of industrial production, manufacturing sales, business climate test points, wholesale and retail sales revenue, the boom light is down 5 points, while the leading and coincident indicators still remain positive.

\subsubsection{People's Feelings for Life}

Since the growths of GDP deflator and consumer price index are divergent, the living cost increases, and the real purchasing power detriments, people have no feeling about the long-term economic boom. The international prices of exports (electronics and machinery) have dropped. The imports have raised more or less, due to the impact of the international raw material prices. The terms of trade have been deteriorating for a long time, and the improvements have been limited in recent years.

\subsubsection{International Stock Market}

Reviewing the global stocks in 2017, except for the U.K. and Mainland China, the global stocks are up in a range of $15-30 \%$. Refer to Table 11 . 
Table 11. Taiwanese stock memorabilia

\begin{tabular}{ccc}
\hline Date & TAIEX Closing & Milestone \\
\hline 1986.10 .17 & $1,003.56$ & Over one thousand points first time \\
1989.06 .19 & $10,105.81$ & Over ten thousand points first time \\
1990.02 .10 & $12,495.34$ & Historical record \\
1997.07 .31 & $10,066.35$ & Over ten thousand points second time \\
2000.02 .09 & $10,008.88$ & Over ten thousand points third time \\
2015.04 .27 & $10,002.58$ & Over ten thousand points fourth time \\
2017.05 .11 & $10,001.48$ & Over ten thousand points fifth times \\
2018.01 .17 & $11,004.80$ & Historic high in 28 years \\
\hline
\end{tabular}

Source: data organized by author.

\subsubsection{Consumer Confidence Index}

In 2017, the initial labor market policy was reformed and many indicators of the private final consumption deteriorated, which offset the substantial improvement of the stock investment orientation in the first half of the year. Gradually improved in the second half of the year, all the six indicators picked up and the consumer confidence in the consumer sector gradually recovered. Refer to Table 12.

Table 12. Domestic consumer confidence index from weak to strong

\begin{tabular}{|c|c|c|c|c|c|c|c|}
\hline & $\begin{array}{c}\text { Consumer } \\
\text { confidence } \\
\text { index } \\
\end{array}$ & $\begin{array}{c}\text { Domestic } \\
\text { price } \\
\text { level } \\
\end{array}$ & $\begin{array}{c}\text { Family } \\
\text { economic } \\
\text { level } \\
\end{array}$ & $\begin{array}{c}\text { Domestic } \\
\text { economic } \\
\text { level } \\
\end{array}$ & $\begin{array}{c}\text { Domestic } \\
\text { job market }\end{array}$ & $\begin{array}{c}\text { Stock } \\
\text { investment } \\
\text { timing }\end{array}$ & $\begin{array}{l}\text { Durable } \\
\text { property } \\
\text { purchase }\end{array}$ \\
\hline 2016 M11 & 77.71 & 51.55 & 78.80 & 72.65 & 107.70 & 66.90 & 88.65 \\
\hline 2017 M10 & 83.34 & 49.55 & 82.60 & 77.45 & 103.80 & 98.50 & 88.15 \\
\hline 2017 M11 & 86.16 & 52.30 & 84.70 & 79.50 & 105.30 & 105.20 & 89.96 \\
\hline Same period last year $(\%)$ & 8.45 & 0.75 & 5.90 & 6.85 & -2.40 & 38.30 & 1.30 \\
\hline Previous period $(\%)$ & 2.82 & 2.75 & 2.10 & 2.05 & 1.50 & 6.70 & 1.80 \\
\hline
\end{tabular}

Source: Economic Research Center, National Taiwan University.

\subsubsection{Turnovers of Wholesale, Retail Sale, and Restaurant}

From January to October 2017, the turnover of the wholesale business as a whole has risen sharply, compared with 2016. Wherein, the turnovers of retail sale and restaurant have been growing at a slower rate. The seasonal fluctuation has greatly affected the turnover. Refer to Table 13.

Table 13. Wholesale, retail sale and restaurant business turnover rates of Taiwan, January-October 2017 (\%)

\begin{tabular}{|c|c|c|c|c|c|c|c|c|c|c|c|}
\hline \multicolumn{12}{|c|}{ Turnover growth rate $(\%)$} \\
\hline 2016 & \multicolumn{11}{|c|}{2017} \\
\hline M1-10 & M1 & M2 & M3 & M4 & M5 & M6 & M7 & M8 & M9 & M10 & M1-10 \\
\hline \multicolumn{12}{|c|}{ Wholesale business } \\
\hline$\underline{-3.09}$ & -0.29 & 14.26 & 6.33 & 2.35 & 4.41 & 5.71 & 4.38 & 5.99 & 7.13 & 3.90 & $\underline{5.22}$ \\
\hline \multicolumn{12}{|c|}{ Retail business } \\
\hline$\underline{1.82}$ & 4.29 & -8.37 & 1.74 & 0.16 & 0.69 & -1.94 & -1.55 & 4.30 & $3 / 37$ & 3.21 & $\underline{0.63}$ \\
\hline \multicolumn{12}{|c|}{ Restaurant business } \\
\hline 3.40 & 14.83 & -8.35 & 2.66 & 5.53 & 2.10 & 0.25 & 2.52 & 4.20 & 1.16 & 2.90 & 2.70 \\
\hline
\end{tabular}

Source: Department of Statistics, Ministry of Economic Affairs (Update 2017.11.23).

\subsubsection{Private Final Consumption Forecast}

There is a pay increase for the civil service system in 2018. However, due to the long-term low-wage environment, the stagnation and polarization of public income, the pension reform, and the long-term conservative trends of private final consumption, Taiwan Research Institute forecasts that the private final consumption in 2018 of Taiwan will grow insignificantly about $2.07 \%$. See Table 14. 
Table 14. Review and outlook of Taiwan's real private consumption and GDP

\begin{tabular}{|c|c|c|c|}
\hline Growth rate & Consumption $(\%)$ & GDP $(\%)$ & Growth multiple \\
\hline $1980 \mathrm{~s}$ & 8.79 & 8.53 & 1.03 \\
\hline $1990 \mathrm{~s}$ & 7.36 & 6.63 & 1.11 \\
\hline $2002-2007$ & 3.20 & 5.63 & 0.57 \\
\hline $2012-2016$ & 2.51 & 2.10 & 1.20 \\
\hline 2012 & 1.82 & 2.06 & 0.88 \\
\hline 2013 & 2.34 & 2.20 & 1.06 \\
\hline 2014 & 3.44 & 4.02 & 0.86 \\
\hline 2015 & 2.63 & 0.81 & 3.25 \\
\hline 2016 & 2.32 & 1.41 & 1.65 \\
\hline 2017(f) & 2.14 & 2.53 & 0.85 \\
\hline 2018(f) & 2.07 & 2.31 & 0.90 \\
\hline
\end{tabular}

Source: Taiwan Research Institute.

\subsubsection{Industrial Production}

The overall industrial production in Taiwan showed higher growth in January-October 2017 than the previous year, while the manufacturing sector accounted for the strongest growth. The industrial production index increased $0.15 \%$ over the previous month and the annual increase rate was $2.85 \%$ in October 2017; the annual growth rate of manufacturing industry was $3.10 \%$, which was a continuous eighteen-month positive growth; from January to October in total, the industrial production increased $3.28 \%$ and the manufacturing increased $4.29 \%$, compared with the same period of last year. The cumulative average of all the four major manufacturing industries between January and October 2017 was growing, compared with the same period of the previous year, and the information-electronics had the highest yearly growth rate of $5.09 \%$.

The production momentum index (output) for the next month's production was 49.8 in October, meaning that the production index of November was expected to decrease slightly. See Table 15.

Table 15. Taiwanese industrial production index

\begin{tabular}{|c|c|c|c|c|}
\hline Annual increase & 2016 M10 & 2016 (M1-10) & 2017 M10 & 2017 (M1-10) \\
\hline Industry & 3.25 & $\underline{0.33}$ & 2.85 & $\underline{3.28}$ \\
\hline Mining and soil taken & -15.29 & $\underline{-9.12}$ & -0.32 & $\underline{0.75}$ \\
\hline Manufacturing & 5.17 & $\underline{0.63}$ & 0.10 & $\underline{4.29}$ \\
\hline Electricity and gas supply & -13.90 & $\underline{-2.10}$ & -3.41 & $\underline{-16.42}$ \\
\hline Water supply industry & 1.62 & $\underline{0.70}$ & 0.13 & $\underline{1.37}$ \\
\hline Construction engineering & -34.85 & $\underline{-7.35}$ & 4.87 & $\underline{-3.81}$ \\
\hline Annual increase & 2016M10 & 2016(M1-10) & 2017M10 & 2017(M1-10) \\
\hline Manufacturing & 5.17 & $\underline{0.63}$ & 3.10 & $\underline{4.29}$ \\
\hline Metal electrical industry & 4.05 & $\underline{-2.38}$ & 0.46 & $\underline{4.61}$ \\
\hline Information electronics industry & 9.19 & $\underline{2.68}$ & 6.20 & $\underline{5.09}$ \\
\hline Chemical industry & 0.67 & $\underline{0.21}$ & 0.82 & $\underline{2.00}$ \\
\hline Staple industry & -0.67 & $\underline{0.10}$ & -0.53 & $\underline{4.63}$ \\
\hline
\end{tabular}

Source: Department of Statistics, Ministry of Economic Affairs (Update 2017.11.23).

\subsubsection{Manufacturing PMI}

The manufacturing PMI in Taiwan climbed to 56.3 in November 2017, with an increase of 2.7 from October, setting a new high since April 2011. The main growth driver came from the sharp increase of new export orders. The enterprises expanded the production. The growth rate of investment and procurement increased from 2016 onwards. See Figure 11. 


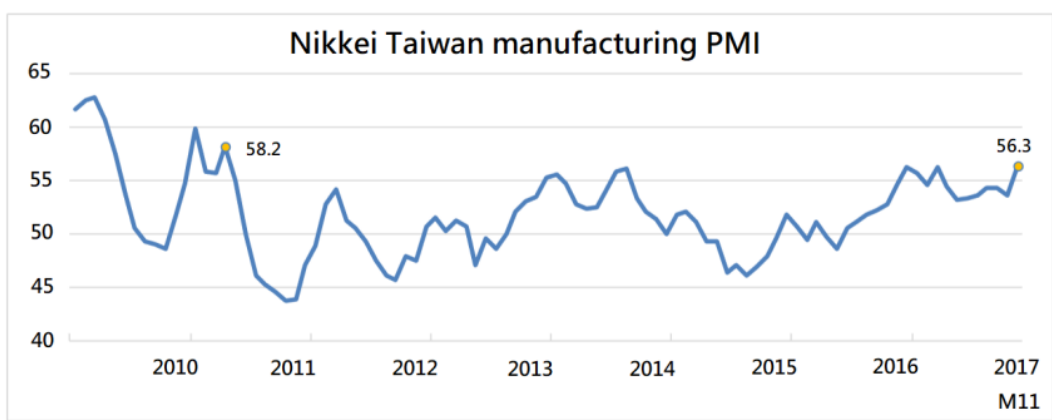

Figure 11. Nikkei Taiwan manufacturing PMI

Source: Markit Economics (2017).

\subsubsection{Capital Goods Import}

Due to the low base period of the domestic capital equipment imports (machinery, precision instruments and semiconductors) in the first quarter of 2016, the growth in the first quarter of 2017 increases significantly, but there is a gradual slowdown in the second half of the year. It is expected that the base period will affect the growth of capital equipment in the first half of 2018. Refer to Table 16.

Table 16. Import growth rate of basic equipment in Taiwan, January-November 2017

\begin{tabular}{lcccccccccccc}
\hline \multicolumn{1}{c}{ Growth rate (\%) } & M1 & M2 & M3 & M4 & M5 & M6 & M7 & M8 & M9 & M10 & M11 & M1-11 \\
\hline Mechanical & 10.5 & 41.2 & 29.9 & 28.1 & -1.9 & -11.8 & -18.9 & -26.4 & -7.2 & -17.2 & -5.8 & $\underline{-1.5}$ \\
Transportation & -21.8 & 29.9 & -0.7 & -7.3 & -0.4 & -7.9 & -8.1 & 23.1 & 59.1 & -23.9 & 24.5 & $\underline{2.8}$ \\
Motor products & -9.5 & 24.7 & 3.1 & 14.2 & 12.2 & 2.4 & 14.2 & 10.0 & 19.3 & 0.4 & 5.2 & $\underline{8.1}$ \\
Precision instruments & 23.2 & 51.6 & 23.0 & 28.9 & -13.1 & -10.4 & -19.1 & -12.4 & 6.2 & -1.6 & -7.7 & $\underline{3.2}$ \\
Semiconductor equipment & 40.8 & 70.3 & 52.5 & 80.9 & -12.7 & -25.6 & -47.6 & -16.3 & -17.8 & -25.6 & -29.7 & $\underline{-7.4}$ \\
\hline
\end{tabular}

Source: Preliminary statistics on import and export trade, Ministry of Finance (Update 2017.12.8).

\subsubsection{Private Investment Forecast}

In 2017, given that the growth of private investment is limited due to the factor of base period, the Premier Lai has tried the best to revise the Basic Labor Law and the Air Pollution Law since his inauguration on September 8, 2017. Meanwhile, stimulated by the "Forward-looking Infrastructure Plan" taking off in 2018, the environment and growth of domestic investment is going to be improved. Taiwan Research Institute forecasts that the annual real private investment growth rate will be $2.81 \%$ in 2018 . Refer to Table 17.

Table 17. Review and outlook of Taiwanese real private investment and GDP

\begin{tabular}{|c|c|c|c|c|}
\hline Year & Growth rate & Private investment & GDP & Growth multiple \\
\hline $1980 \mathrm{~s}$ & & 10.29 & 8.53 & 1.21 \\
\hline $1990 \mathrm{~s}$ & & 9.43 & 6.63 & 1.42 \\
\hline $2002-2007$ & & 7.21 & 5.63 & 1.28 \\
\hline $2012-2016$ & & 3.22 & 2.10 & 1.53 \\
\hline 2012 & & -0.35 & 2.06 & -0.17 \\
\hline 2013 & & 7.09 & 2.20 & 3.22 \\
\hline 2014 & & 3.58 & 4.02 & 0.89 \\
\hline 2015 & & 3.02 & 0.81 & 3.73 \\
\hline 2016 & & 2.77 & 1.41 & 1.96 \\
\hline 2017(f) & & 0.07 & 2.53 & 0.03 \\
\hline 2018(f) & & 2.81 & 2.31 & 1.22 \\
\hline
\end{tabular}

Source: Taiwan Research Institute.

\subsubsection{Export orders}

In terms of export order, continuing the positive growth in 15 months, a cumulative increase of $9.0 \%$ had being achieved from January to October 2017. The recent growth has slowed down. The major export markets in the 
regions of ASEAN (Association of Southeast Asian Nations) have been negatively affected. The major exports excluding chemicals and information products in October are still higher than the same period (January-October) of 2016, while the growth of the rest is relatively slowdown. Refer to Table 18.

Table 18. Taiwan's export order in January-October 2017

\begin{tabular}{lcc}
\hline Export purchase order growth rate (\%) & $2016(\mathrm{M} 1-10)$ & 2017 (M1-10) \\
\hline Overall & -3.38 & 10.0 \\
Mainland China and Hong Kong & -2.59 & 15.44 \\
ASEAN & 2.00 & -5.86 \\
Japan & -19.93 & 16.27 \\
Europe & -3.66 & 12.67 \\
United States & -0.48 & 8.01 \\
\hline
\end{tabular}

Source: Department of Statistics, Ministry of Economic Affairs (Update 2017.11.20).

Thanks to the recovery of global economy and the gradual growth of foreign demand, the export orders increased by $1.5 \%(\mathrm{~m} / \mathrm{m})$ to 44.60 billion NTD in October, recording a new monthly high, further increasing $9.2 \%$, compared with the same month of the last year, a positive growth for 15 consecutive months. The orders for major goods show positive growth, but the growth rate slows down, compared with the last month. Wherein, the growths of metal and its products reach double-digit, showing a marked increase. The growth scale of optical equipment gradually flattens.

\subsubsection{Export Status}

Due to the low base period and the emergent order effect, the export growth in 2017 is remarkable. In second half of the year, the growth of two digits still can be seen. The exports in major regions hit a new high for 5-6 years. The export growth rate in January-November 2017 was higher than the same period of 2016. The overall growth throughout the year is forecasted optimistically. Refer to Table 19.

Table 19. Taiwan's major export growth rates

\begin{tabular}{lcccc}
\hline Export growth rate & $2016(1-11)$ & Proportion $(\%)$ & $2017(1-11)$ & Proportion $(\%)$ \\
\hline Overall & -3.1 & - & 13.4 & - \\
Mainland China and Hong Kong & -2.1 & 39.8 & 15.9 & 40.8 \\
ASEAN & -2.5 & 18.3 & 14.5 & 18.5 \\
Japan & -1.0 & 7.0 & 6.0 & 6.6 \\
USA & -3.4 & 12.0 & 10.1 & 11.7 \\
\hline
\end{tabular}

Source: Preliminary statistics on customs export trade, Ministry of Finance (Update 2017.12.8).

\subsubsection{Real Export Forecast}

As for the global economic growth recovery forecast, the exports in 2017 will reach a new high for the recent six years. In 2018, the export growth to the major trading countries will slow down relatively, thus that the entire exports growth will be restricted. The forecast growth of the output of real goods and labor services for the year of 2018 will be $2.72 \%$. Refer to Figure 12 .

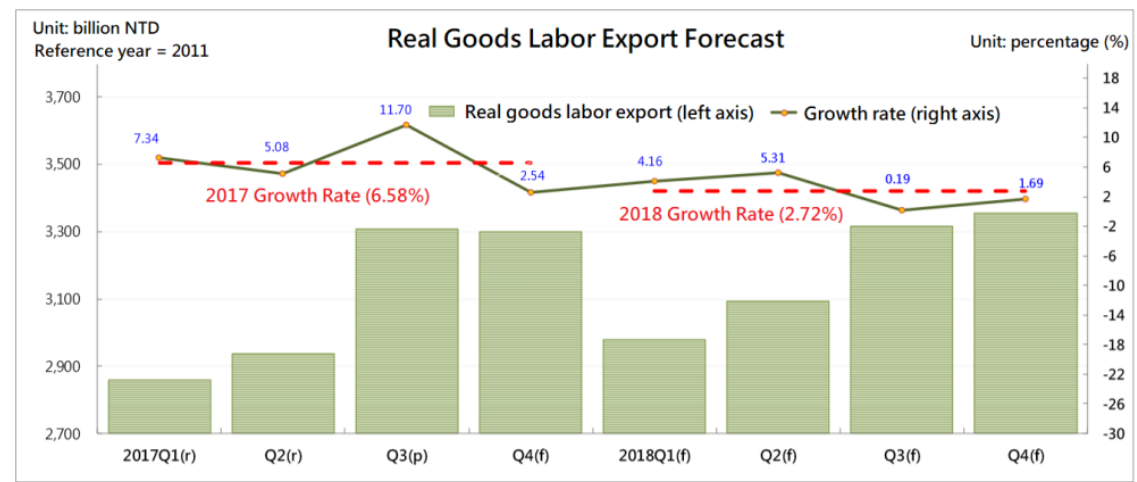

Figure 12. Taiwan's real exports forecast for 2018

Source: Taiwan Research Institute. 


\subsubsection{Import Status}

Taiwan's imports had being continued to grow for 15 months, with cumulative growth rate of two digits in January-November 2017. Machinery items and precision instruments showed negative growth in November though. Electronic components, chemicals, information and communications, basic metals and transportation equipment were also same with two digits growth. Refer to Table 20.

Table 20. Taiwan's import growth rate in recent years

\begin{tabular}{lcccc}
\hline \multicolumn{1}{c}{ Import growth rate $(\%)$} & $2016(\mathrm{M} 1-11)$ & Proportion (\%) & 2017 (M1-11) & Proportion $(\%)$ \\
\hline Overall & -4.0 & - & 12.6 & - \\
Mainland China and Hong Kong & -3.3 & 19.7 & 13.1 & 19.9 \\
ASEAN & -8.1 & 11.8 & 15.0 & 12.1 \\
Japan & 3.9 & 17.7 & 2.9 & 16.2 \\
Europe & -0.4 & 12.5 & 8.5 & 12.0 \\
United States & -2.4 & 12.4 & 5.2 & 11.6 \\
\hline
\end{tabular}

Source: Preliminary statistics on import and export trade, Ministry of Finance (Update 2017.12.8).

\subsubsection{Real import forecast}

Due to the conservative domestic consumption, the sluggish investment momentum and the recession in import demand for capital equipment, Taiwan Research Institute forecasts that the full-year import growth rate in 2018 will be $3.28 \%$, in terms of real goods and labor services, as shown in Figure 13.

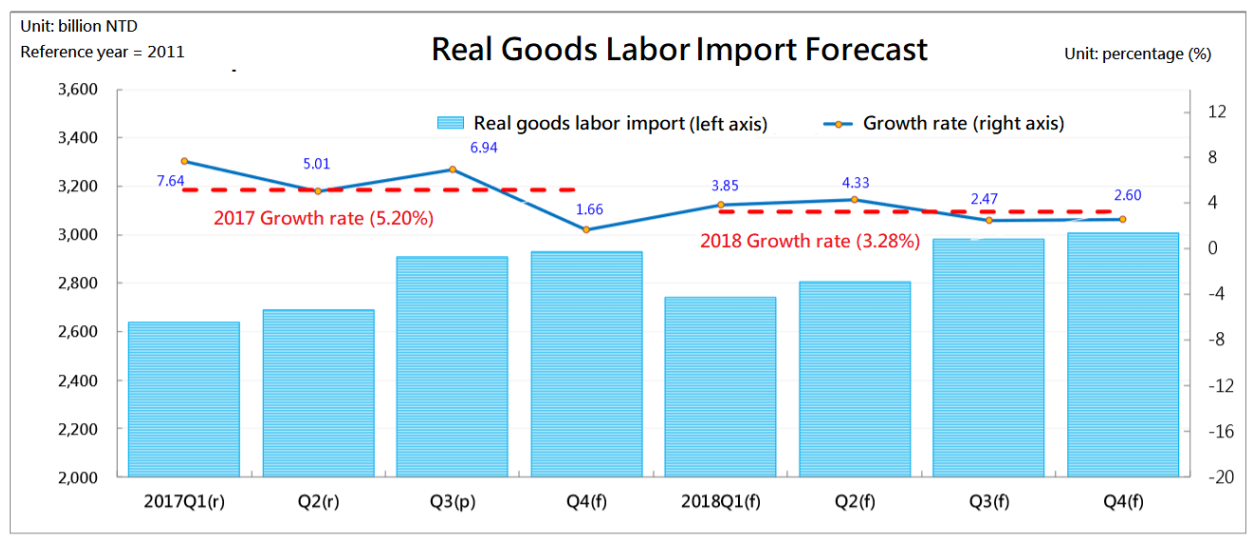

Figure 13. Taiwan's real imports forecast 2017-2018

Source: Taiwan Research Institute.

\subsubsection{Taiwan's Economic Growth Rate and Its Composition}

Figure 14 shows Taiwan's economic growth rates over the past ten years, which were volatile in 2007-2010 and trended flatly in the later, with an average rate of about $2.5 \%$. The contribution factors of the economic growth rate for 2017-2018 are explained as follows.

(1) The net outputs contribute positively to the economic growth: the domestic demand contributed about $1.17 \%$ in 2017, the net output contribution increased from $-0.53 \%$ in 2016 to $1.36 \%$ in 2017, and the domestic demand will contribute about $1.94 \%$ in 2018.

(2) The economic growth rate is expected to reach more than $2 \%$ in seasons: the growth rates in all seasons in 2017 are above $2 \%$, reaching the highest level of $3.1 \%$ in the third quarter.

(3) The private final consumption has become an important support: the private final consumption in the real growth was $2.18 \%$ in 2017 , with a contribution of $1.21 \%$ to the entire GDP growth rate; the private final consumption growth rate in 2018 is estimated to be about $2.0 \%$, slowed down for the fourth consecutive year.

(4) The domestic non-governmental investment growth was sluggish: the growth rate of real private investment in 2017 was $-0.36 \%$, which contributed negatively to the GDP growth. In 2017, the governmental investment grew more obviously with a real growth rate of $5.03 \%$. 


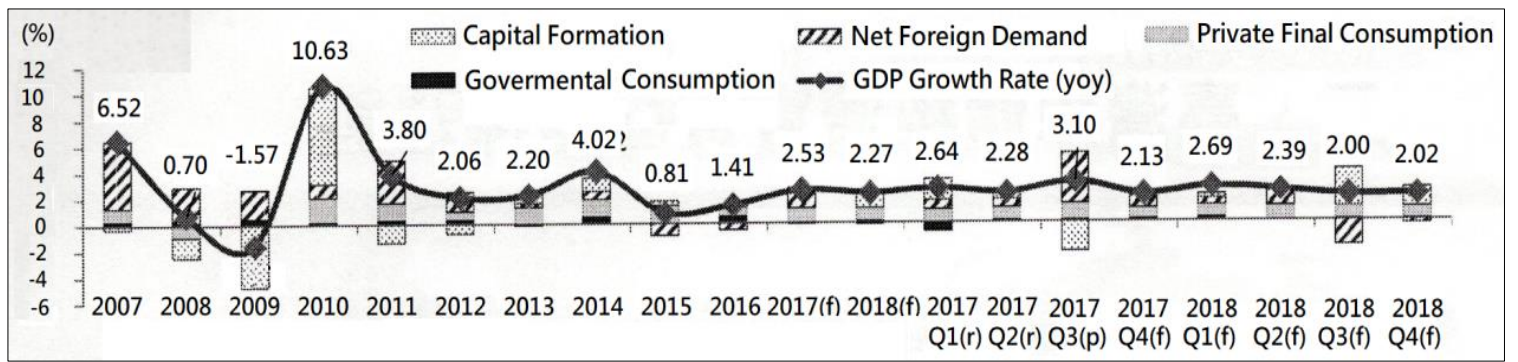

Figure 14. Taiwan's economic growth rates over the years and their contribution factors

Note. (r) revised data, (p) preliminary statistics, (f) forecasted data.

Source: National Income Statistics and Domestic Economic Outlook before the third quarter of 2017, released by Accounting and Statistics Office, 24 November 2017; for the fourth quarter of 2017, the full year of 2017 and the estimated values for 2018 were released by Chung-Hua Institution for Economic Research, December 19, 2017.

Looking further away from 1980, Figure 15 shows the share changes in Taiwan's GDP, in terms expenditure compositions.

The share of foreign trade sector was up, in which the export was about $47.27 \%$ in 1988 , and up $30.05 \%$ to $77.32 \%$ by 2018 .

The share of import in 1988 was about $62.52 \%$ in 1988 , and up to $69.51 \%$ in 2018 , with an average increase of $6.99 \%$.

The share of domestic demand sector declined, in which the private final consumption dropped from $59.43 \%$ to $55.27 \%$, with a decrease rate of $4.16 \%$; the domestic investment dropped from $36.51 \%$ to $22.61 \%$, with a decrease rate of $13.90 \%$.

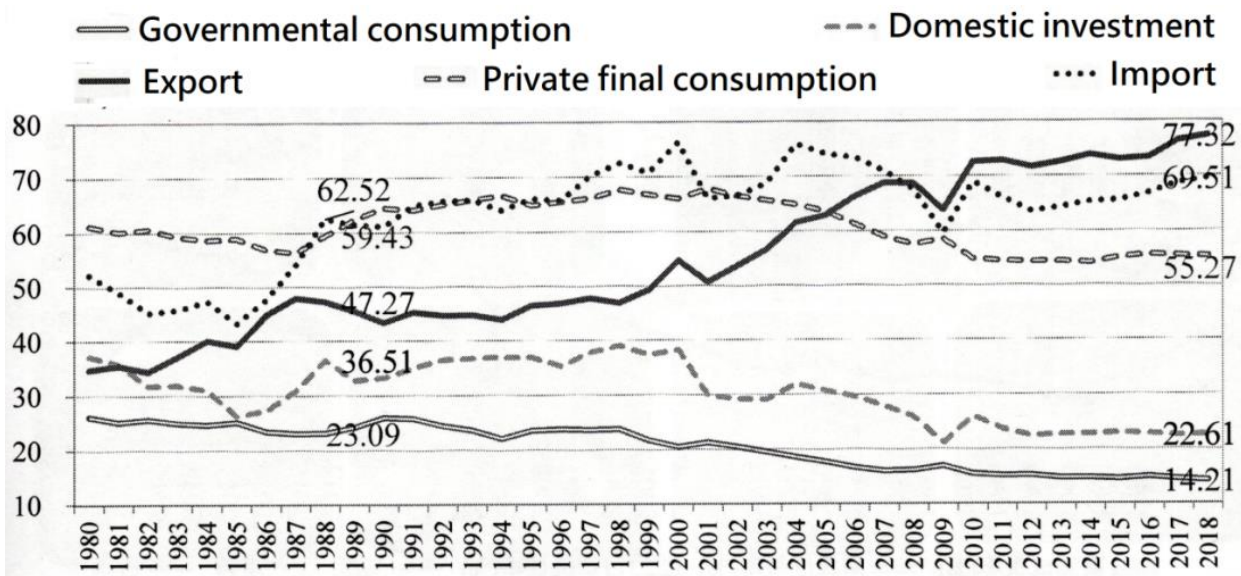

Figure 15. Taiwan expenditure compositions in GDP $(\%)$

Note: The data was calculated based on the real value of chain (2011 as a reference value).

Source: Data estimated based on information provided by Accounting Office before 2016; 2017-2018 data estimated from the forecast released by the case study of Chung-Hua Institution for Economic Research, December 19, 2017.

\subsection{Summary: Review and Outlook}

Benefiting from the favorable international climate, the momentum of Taiwan's economic indicator continues to grow, such as industrial production, prosperity light, export order, import and export amounts. Taiwan Research Institute estimated the economic growth rate of 2017 to be $2.53 \%$. Looking forward to this year (2018), the advanced countries will perform similarly and the global trade growth will slow down. The economic growth rate is expected to be $2.31 \%$, slightly down from the previous year (2017), as shown in Figure 16 and Figure 17. 


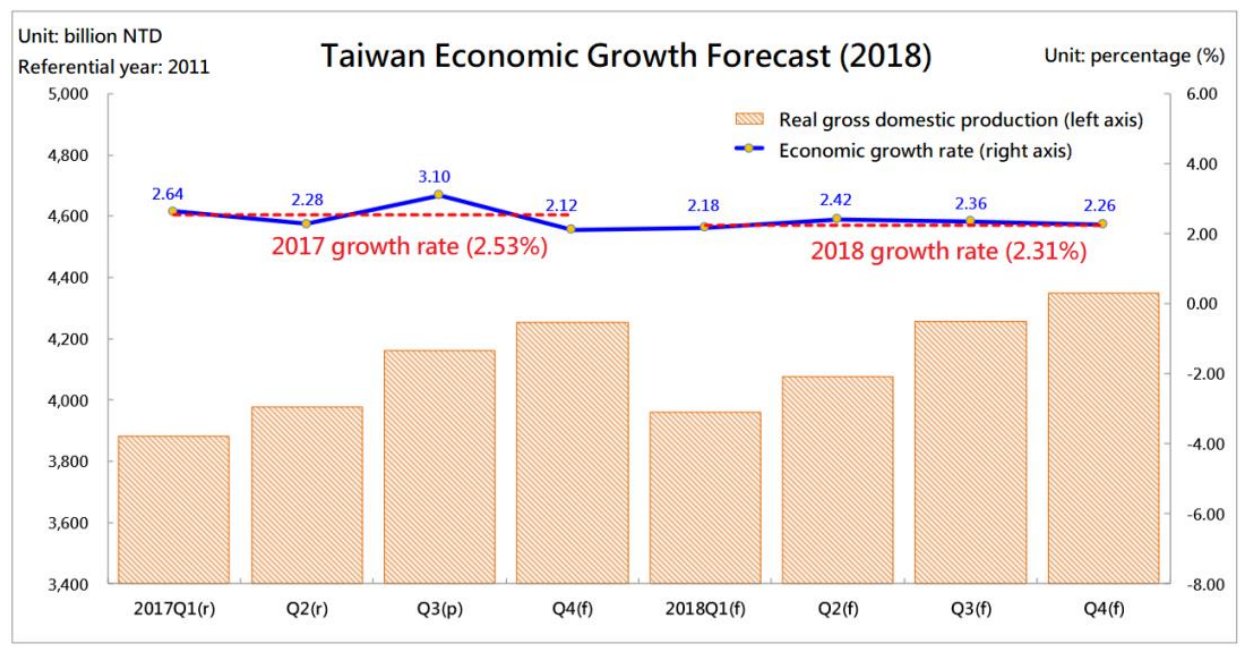

Figure 16. Taiwan's economic growth rates review and forecast (2017-2018)

Source: Taiwan Research Institute.

\begin{tabular}{|c|c|c|c|c|c|c|c|c|c|}
\hline \multicolumn{4}{|c|}{2017} & \multirow{2}{*}{$2017(f)$} & \multicolumn{4}{|c|}{2018} & \multirow{2}{*}{ 2018(f) } \\
\hline Q1(r) & Q2(r) & Q3(p) & Q4(f) & & Q1(f) & Q2(f) & Q3(f) & Q4(f) & \\
\hline Real GDP & 2.28 & 3.10 & 2.12 & $\underline{2.53}$ & 2.18 & 2.42 & 2.36 & 2.26 & 2.31 \\
\hline Private final cons. 1.81 & 2.05 & 2.69 & 2.00 & $\underline{2.14}$ & 2.08 & 2.09 & 2.05 & 2.04 & 2.07 \\
\hline G'ment cons. & 0.84 & 0.83 & 0.95 & -0.45 & 1.91 & 0.20 & 0.47 & 0.39 & $\underline{0.70}$ \\
\hline Fixed cap. form. 4.82 & 0.80 & -3.65 & 2.17 & $\underline{0.76}$ & 2.07 & 2.80 & 4.92 & 4.83 & 3.67 \\
\hline Private invest. & 0.26 & -5.18 & 1.90 & 0.07 & 1.49 & 1.96 & 4.10 & 3.68 & 2.81 \\
\hline G'ment invest. & 8.73 & 6.04 & 0.50 & 4.99 & 7.43 & 6.81 & 9.35 & 12.19 & 9.40 \\
\hline Public invest. & -7.49 & -3.28 & 8.62 & $\underline{3.39}$ & 1.78 & 6.74 & 8.10 & 0.32 & 3.58 \\
\hline Goods labor exp. 7.34 & 5.08 & 11.70 & 2.54 & $\underline{6.58}$ & 4.16 & 5.31 & 0.19 & 1.69 & $\underline{2.72}$ \\
\hline Goods labor imp. 7.64 & 5.01 & 6.94 & 1.66 & $\underline{5.20}$ & 3.85 & 4.33 & 2.47 & 2.60 & $\underline{3.28}$ \\
\hline CPI yearly increase $\quad 0.78$ & 0.56 & 0.75 & 0.46 & 0.64 & 0.92 & 1.01 & 0.76 & 0.82 & 0.88 \\
\hline WPI yearly increase 2.30 & -0.70 & 0.82 & 0.86 & $\underline{0.82}$ & 0.06 & 1.58 & 1.34 & 1.28 & $\underline{1.06}$ \\
\hline Exch. rate (NT/US) 31.10 & 30.27 & 30.28 & 30.20 & 30.46 & 30.36 & 30.48 & 30.57 & 30.58 & $\underline{30.50}$ \\
\hline Unemployment rate 3.80 & 3.69 & 3.83 & 3.78 & 3.78 & 3.69 & 3.65 & 3.78 & 3.75 & 3.72 \\
\hline
\end{tabular}

Figure 17. Taiwan economic growth and forecast (2017-2018) - including breakdown

Source: Taiwan Research Institute.

Reviewing Taiwanese economic performance in 2017, the external demand coincides with the international economic recovery and the hi-tech product upgrade cycles. Taking advantage of this trend, the economic performance of Taiwan improves. The stock market in Taipei hits a record high. Moreover, the time-span of TAIEX over 10,000 points is maintained the longest ever.

In the private final consumption sector, due to the policy adjustment in the labor market at the beginning of 2017, the domestic product price and employment prospects were adversely affected. The annual pension reform policy suppressed some private final consumption. On the contrary, in the second half of the year, the bearish news completely out of domestic market, so the stock market hit record highs plus the bullish news of salary increase for civil service system, making the private consumption confidence recovered gradually. However, due to the long-term low-wage environment, the growth of general public section has always being sluggish and shows an M-typed polarization. The overall domestic consumption trend remains pessimistic bias due to the private consumption willingness tends to be conservative.

In terms of private investment, although the government actively improves the basic environment, to which the enterprises are always paying attention, the domestic enterprises' investment is still concentrated in the high-tech industry (e.g., the electronics). Meanwhile, the growth of imports of semiconductor equipment and machinery items had declined in last year (2017). The expansion scale of business operation in traditional industries and small and medium-sized enterprises is limited. In the long term, the issues of excessive savings and idle funds remain serious. The profited manufacturers are reluctant to invest. Basically, the major driver of Taiwanese economic growth will rely on the governmental investment in forward-looking infrastructure. 
In terms of international trade, due to the U.S. foreign exchange policy report released by the U.S. Treasury Department on the international trade, the central banks of the major countries in the world reduced their interventions and let the exchange rate appreciated. As a result, the exporters generally face a diminished competitiveness in terms of exchange rate and price. Looking forward the normalization of the U.S. currency in the year of 2018, China will gradually move into a cycle of raising interest rates and execute the policy of tax reform. It is expected that Chinese monetary policy will moderately tighten in the future to further affect the decision-making of global central banks, while the pressure of appreciation of Taiwan dollar is expected to ease. The import space will be restrained due to the factor of high base period.

On the whole, since of the cyclical recovery of the international economic climate and the optimistic economic growth in 2017, it is precisely the best opportunity for the Taiwanese government to solve the long-term economic problems accumulated in the past and actively take the lead in revitalizing domestic investment. In the past year, $2+5$ industrial innovation, forward-looking infrastructures, new south policy, and the new cabinet to actively address the five shortages of enterprises with an announcement of $3 \%$ pay raise for public servants, the people in the country welcome the determination of the government to solve the long-term downturn of investment at last.

Forward-looking the economic growth in Taiwan for 2018, there are still many uncertainties, including the trend of global monetary policy, the impact of international hot money movement, the trend and volatility of international financial exchange rates, the economic development in Mainland China and the trend of cross-strait relations, the progress of governmental implementation of forward-looking infrastructure projects, as well as the policy and style of the newly appointed president of central bank and so on, all of which will affect the subsequent performance of the domestic economy in 2018, while the follow-up development is worthy of our further observation.

\section{Monetary Policy of Major Countries}

\subsection{The Dollar and the Yuan}

Taking the exchange rate of 6.75 Yuan to one dollar in November 2016 as base period, the RMB (Renminbi) depreciated to around 6.95 in the first half of 2017 and rose to around 6.65 in October 2017. From October 2017 till now (January 2018), the RMB exchange rate fluctuated between 6.4-6.70.

Since the 1970s, the Fed had raised interest rates five times on large scale, followed up with significant declines of the US dollar. Theoretically, the dollar's rise is suppressed by the interest rate hike due to the inflation.

In 2014-2017, the DXY reached a highest of 103.3 in December 2016. In the second half of 2014, Fed's monetary policy changed from dove to hawk. DXY soared more than $25 \%$ in one year. Before the first rate hike in December 2015, DXY once again broke 100 to 100.17 on November 30, 2015 and then slipped. Meanwhile, UBS said that the dollar was overvalued relatively to G10 currencies in 2016. In November 2016, Paulsen, a capital manager at Wells Fargo, predicted that the U.S. dollar would have a great deal to decline in 2017, because the dollar was going to decline after the interest rates hike. Moreover, in November 2017, several large banks in Europe and the United States forecasted the bearishness for the U.S. dollar in 2017. Meanwhile, JP Morgan expected the weakness of the U.S. dollar against major currencies due to the concerns about the protectionism of President Trump. In addition, during his campaign in 2016, Trump loudly said "the trade surplus opponents manipulate the exchange rate, resulting in a great impact on the trend of dollar." In November 2016, the dollar was strong again after the election speech of Trump, and climbed to 103.3 on December 28, 2016, then declined, as shown in Figure 18.

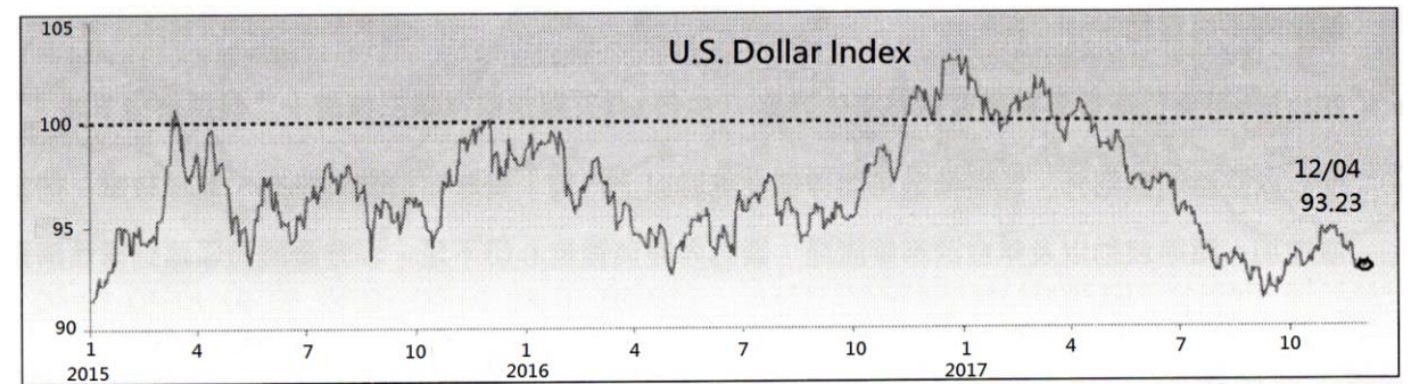

Figure 18. U.S. Dollar Index (DXY)

Source: National Development and Reform Commission (2017). 
The background of RMB appreciation in 2017 is that the weakening of the U.S. dollar and the resurgence of RMB in Mainland China. Although the renminbi was predicted to be bearish by the end of 2016, instead to break the threshold of 7, the renminbi rose 5\% in the first nine months of 2017. Prior to August, the renminbi appreciation was a result from "bearishness converted to bullishness" in the overseas market. However, from the last week of August to the early September, the RMB appreciation was a result of counter-bearishness forced by domestic market. A series of foreign exchange control measures at the end of 2016 substantially tightened Chinese foreign direct investment and personal remittances. Outward direct net outflows in the first three quarters of 2017 decreased by 56\% over the same year. Direct investment turned from deficit to surplus, and the bank deficit in foreign exchange settlement declined 73\%. The Chinese economic growth in 2017 is better than the expected. The positive growth of the second quarter foreign exchange reserves was announced on August 7 , 2017, boosting the RMB to take more confidence, the accumulated amounts of long-term and spot were surpluses for the first time. On August 9, the middle price and the CNY (Chinese Yuan Renminbi) broke 6.70, and there was another $1 \%$ rise on August 25. At the meantime, the panic settlement was coming out, RMB rose to the 6.43 on September 8. When Chinese central bank (i.e., People's Bank of China) canceled the foreign exchange risk reserve on September 11, the CNY fell back to 6.50. The CNY had been oscillating between 6.50 and 6.70 from early October to November.

After the 19th National Congress of the Communist Party of China, because the opening up benefits the strength of RMB for 2018, Chinese national financial work conference in July resolved to expand the financial opening up, the primary task is the reform of RMB exchange rate formation mechanism.

The financial opening up focused on four major aspects:

(1) RMB internationalization.

(2) The advancement of B\&R (the Belt and the Road) construction.

(3) The free trade zone construction, transforming and adjusting the management of economy, clearly putting forward the implementation of negative inventory management.

(4) The development of new international investment platforms possessing of Chinese elements, such as Asian Infrastructure Investment Bank, Silk Road Fund, and BRICS Development Bank.

Xiaochuan Zhou, President of People's Bank of China, spoke at the People's Daily about the major tasks after 19th National Congress of the Communist Party of China:

(1) Expanding the Mainland China's opening up to the outside world.

(2) Promoting and optimizing the economy through competition.

(3) Boosting the direct financing ratio of funds needed for the Belt and the Road and the emerging industries, so as to reduce the debt ratio and the financial system risk.

(4) Lifting the restrictions on the proportion of foreign ownership, in which the stocks in free trade zones and Hong Kong proceed first.

(5) The proportion of shares held by the securities, the fund management and the futures companies that are foreign-funded can reach $51 \%$ of the total shareholding.

(6) After three years of implementation, the shareholding ratio will be not limited.

(7) The cap on the foreign ownership of Chinese banks and financial management companies, namely, the shareholding limitation of $20 \%$ for a single and $25 \%$ for the total is canceled.

For the full circulation of $\mathrm{H}$ share, the version of the pilot program of full circulation will be settled down most quickly in the first quarter of 2018. The international markets estimate that shares of market capitalization of at least 950 billion Yuan will join the Hong Kong stocks. Can the full circulation of $\mathrm{H}$ shares of Chinese companies listed in Hong Kong reproduce the same huge prosperity wave as the A share reformed as the split shares in Shanghai and Shenzhen stock markets in 2005? The answer is yes. For example, shortly after the Chinese stock market crash in October 2015, the original IPO companies in Taiwan quietly left for Shanghai, Shenzhen and Hong Kong. In particular, the high-tech enterprises, playing as a major role of Taiwan's IPO, such as Goodix Technology (a subsidiary of MediaTek) and subsidiary of L\&K Engineering (in Suzhou) listed in Shanghai respectively in October 2016 and 2017, and Foxconn Interconnect Technology Limited (the world's fifth largest connector factory) had transferred to the Hong Kong market.

The conclusion is that there will be some support for RMB in 2018, but the volatility will increase and the fundamentals will be stable. The counter-cyclical factor will ease the unilateral expectation, it is expected that 
the RMB will fluctuate between 6.40-6.85. In addition, the DXY was 91-95 after September 11, 2017, but the RMB held steady between 6.50-6.70. Does this mean that the RMB has decoupled from the dollar, thus showing the reformation signs of RMB exchange rate formation mechanism. At present, the three major statistics that reflect the quality of the economic growth in Mainland China have shown steady performance. The growth rates of industrial production, retail consumption and fixed asset investment have remained steady at slightly over 6\%, 7\% and 10\% separately. The People's Bank of China announced in 2017 that the mid-price quote model will introduce a counter-cyclical factor (i.e., RMB supply and demand factors included in the formula) to increase the discretionary space. The unilateral expected hedging effect of RMB exchange rate against US dollar will be relieved and RMB will not easily repeat the same rapid depreciation as the mistakes happened in 2016.

\subsection{The United States Monetary Policy Trends}

Powell, the successor of the Fed chairman Yellen, said that he expected the Fed to slightly raise interest rates in 2018 and gradually shrink the balance sheet. It seems that the policy line of current Fed chairman Yellen will continue. Among Fed's seven members, four new members are needed to be appointed by Trump. How to maintain the independence of monetary policy to reduce the possibility of guidance from Trump is probably crucial to whether the Fed will continue to maintain its professional and stable operation in the future.

\subsection{Six Countries' Currency Performance - European Economic Growth Better than Expected}

In July and September 2017, the Bank of Canada raised its benchmark interest rate by 1 yard from $0.5 \%$ to $1 \%$, which is the first interest rate rise for seven years in Canada, resulting that the exchange rate of Canadian dollar to the U.S. dollar hits a two-year high. The European Central Bank (ECB) announced at its monetary policy meeting in October 2017 to reduce the scale of monthly bond purchase. From January 2018, the monthly bond purchase level will be cut from 60 billion euros to 30 billion euros. Meanwhile, for the time point of ECB to execute the normalization of interest rate, it still needs to be "patient" because salary growth is still fairly flat.

\subsection{From 2017 to Present, Exchange to the Dollar Has Risen in Most Countries}

Since early 2017, the exchange rate of multi-currency against the U.S. dollar has shown an upward trend. Among them, the exchange rate of the euro against the U.S. dollar rose double digit, about $11.20 \%$. On December 8 , 2017, the first stage of Brexit negotiation between the U.K. and the EU was completed; namely, the break-up fee and the protection of the right of EU citizens in the British had been settled down, successfully entering the second phase of trade negotiations. The overall Brexit procedure is expected to be complete in March 2019. The pound will be appreciated strongly. In the Asian region, the exchange rate of the local money against the United States dollar showed more appreciation. The appreciation of the renminbi was about $4.8 \%$, the Taiwan dollar was nearly $7.0 \%$ and the Won was up $9.5 \%$. In the southeast Asian countries, the appreciation of the Malaysian ringgit was about $9.1 \%$, the Thai baht was about $8.9 \%$, the Singapore dollar was about $6.8 \%$; the exchange rates of Indonesian rupiah and Philippine peso increase about 3\%.

\subsection{Interest Rate Policy - Most Countries will (Already) Enter a Cycle of Rate Hikes}

Bank of England (BOE) announced in November 2017 to raise the benchmark interest rate by 1 yard to $0.5 \%$; this is the first interest rate rise since July 2007.

Malaysia's economic growth in the third quarter of 2017 was about $6.2 \%$. Inflation rose to $4.3 \%$ in September, exceeding the target level (3-4\%). In November 2017, Malaysia announced that it would maintain the benchmark interest rate at $3 \%$, but said: "as the economy grows more robust, the currency commissioner will evaluate the current monetary easing policy. The next interest rate decision will be made on December 30, 2017."

South Korea announced a $0.25 \%$-to- $1.5 \%$ rate hike in November 2017. This is the first rate hike in six years and also the first country in Asia to raise interest rates.

Canada, British and South Korea followed the United States into the cycle of rate hikes. Table 20 shows that the most countries have not raised their interest rates yet, but the deflation has diminished, except the monetary easing. 
Table 20. Interest rate, price and economic growth rate in the money market of major countries in the world (unit: \%)

\begin{tabular}{lcccccc}
\hline & \multicolumn{3}{c}{ Official (policy) interest rate } & \multicolumn{3}{c}{ Price, economic growth rate } \\
\cline { 2 - 7 } \multicolumn{1}{c}{ Country } & 2016.11 & 2017.11 & 2017CPI(f) & 2016GDP(f) & 2017GDP(f) & 2018GDP(F) \\
\hline Taiwan & 1.38 & 1.38 & 0.7 & 1.5 & 2.2 & 2.2 \\
U.S. & 0.50 & 1.25 & 2.0 & 1.6 & 2.4 & 2.4 \\
Japan & $(0.1)$ & $(0.1)$ & 0.4 & 1.0 & 1.6 & 1.1 \\
U.K. & 0.25 & 0.50 & 2.6 & 1.8 & 1.5 & 1.1 \\
Eurozone & 0.00 & 0.00 & 1.5 & 1.7 & 2.2 & 2.0 \\
Australia & 1.50 & 1.50 & 2.1 & 2.5 & 2.4 & 2.6 \\
China & 4.35 & 4.35 & 1.8 & 6.7 & 6.8 & 6.5 \\
Korea & 1.25 & 1.50 & 2.1 & 2.9 & 3.0 & 3.0 \\
India & 6.25 & 6.00 & 3.3 & 7.1 & 6.8 & 7.4 \\
Brazil & 14.00 & 7.50 & 3.5 & $(3.6)$ & 0.9 & 2.1 \\
New Zealand & 1.75 & 1.75 & 2.0 & 3.5 & 2.5 & 2.5 \\
Malaysia & 3.00 & 3.00 & 3.3 & 4.2 & 5.5 & 5.2 \\
\hline
\end{tabular}

Source: Central Bank; Global Insight: Trading Economics, 2017.11.

\section{Conclusions with the Major Uncertainties in the Future}

Looking back on the global economic recovery in 2017, the outlook for the coming year is promising, but there are also some uncertainties that may affect this optimistic forecast.

\subsection{Trends of Major Countries' Monetary Policy and the Content and Progress of Tax Reform Implementation}

The first is the gradual shift of monetary policy in major countries/regions:

(1) The United States - to raise interest rate and shrink balance sheet: first, the Fed raised interest rate once again in December 2017. Jerome Powell, the successor of Fed's chairman, said "the monetary policy set by the current Fed chairman, Yellen, will continue."

(2) The Eurozone - to reduce debt purchase: the European Central Bank (ECB) reduces the monthly bond purchase scale from 60 billion euros to 50 billion euros, starting from January 2018 onwards.

(3) Japan - to continue the easing policy: BOJ (Bank of Japan) believes that Japan is still far from the inflation target, so the easing measures will be still implemented.

(4) Mainland China - to tighten liquidity in the market: the People's Bank of China (PBC) adopts such tactics as the excessive delivery of MLF (Multilateral Fund), the revival of 28-day reverse repurchase, and the continuous increase of reverse repurchase to maintain the tight market liquidity expectations.

\subsection{Major Countries to Introduce Tax Cuts or Tax Reform Programs}

Following the passage of tax reform in the United States by the end of 2017, which will be implemented in early 2018, it is expected that by attracting global funds and driving global companies to invest or build factories in the United States, which will undermine the competitiveness of other countries in economic development. In view of this, tax cut act will become a top priority in the major countries in the world in 2018.

(1) The United States (Tax Cuts and Jobs Act, TCJA): to simplify the way of income tax levy and increase the standard tax deduction; to increase the threshold of estate/gift tax; to reduce the corporate tax from $35 \%$ to $20 \%$.

(2) Europe (British and French tax cuts): the United Kingdom will reduce the corporate income tax and capital gains tax; France will reduce the mandatory tax amount, by implementing the "Corporate Competitiveness and Employment Net Tax Relief Benefit Act."

(3) Japan-tax reform: two-stage tax rate reform; a positive salary increase; a tax cut for the enterprise for equipment investment; a tax cut to $20 \%$ for the enterprises for innovation investment.

(4) Taiwan (tax reform in early 2018): a new tax system for dividend income (in an optional way); a comprehensive tax system reform, i.e., a 6-level is simplified to 5-level; an increase of levy thresholds of salary income tax.

The above tax reduction/reform measures may cause many countries to join the tax reduction competition, thus exacerbating the government fiscal deficit.

\subsection{The International Prices of Crude Oil and Commodity}

With international crude oil inventories tightening, the Brent oil prices had risen by more than $30 \%$ since July 
2017. Recently, due to the shutdown of Forties oil piping system in North Sea oilfield, triggering a plunge in global crude oil supply, London Brent crude oil futures prices broke 65 to 65.7 USD/barrel.

The OPEC (Organization of Petroleum Exporting Countries) and non-OPEC large oil-countries headed by Russia reached an agreement in early December 2017 that they would prolong their oil production cut to the end of 2018.

Goldman Sachs raised the Brent and West Texas oil prices for 2018 from 58 and 55 to 62 and 57.5 USD/barrel respectively. Credit Suisse on December 11, 2017 also raised the Brent average crude oil price from 53 to 60 $\mathrm{USD} / \mathrm{barrel}$.

The International Commodity Price Index (CRB) remained above 180 since June 2017, further surpassing 190 in November, and closing at 184.72 on December 6, due to the continuous decline of DXY and the recovery of global raw materials demand.

For the Brent crude oil price movements and the International Commodity Price Index (CRB Index), see Figure 19.
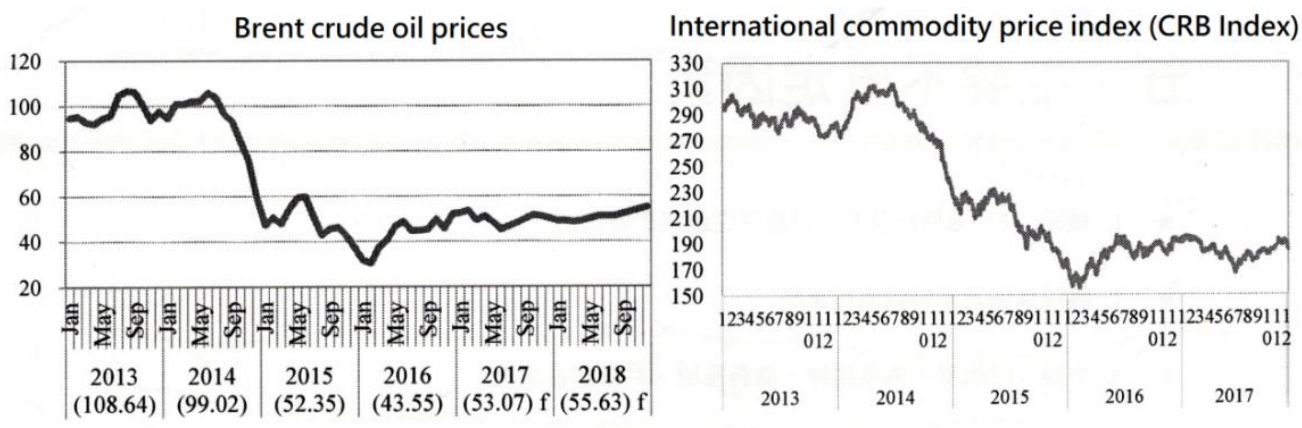

Figure 19. International crude oil and commodity prices

Source: EIA (2017); Investing.com.

\subsection{Factors in Mainland China: Slower Growth, Debt Risk, Structural Transformation}

There are many disagreements about the growth trends in Mainland China after the 19th National Congress of the Communist Party of China. IHS Markit predicts that the economic growth rate of China in 2018 will be 6.5\%, the lowest level since 1991. In addition, other institutions forecast that the economic growth in Mainland China in 2018 will fall below 6\% (e.g., $5.8 \%$ by EIU).

Taiwan's export growth rate for January-November 2017 is 13.1\%. Exports to Mainland China and Hong Kong are the largest contributor, accounting for $7.3 \%$, followed by $2.1 \%$ to the six countries of ASEAN. In November 2017, the amount of exports to Mainland China and Hong Kong is 12.506 billion US dollars, a year-on-year increase of $16.8 \%$. This is the 17th consecutive month of positive growth. According to BIS (Bank for International Settlements) statistics, the debts of non-financial institutions in Mainland China account for 255.9\% of the GDP in the second quarter of 2017, of which the private sector debt accounted for about $163.4 \%$ (see Figure 20), the household debt accounted for $46.8 \%$, and $42.3 \%$ for the government debt.
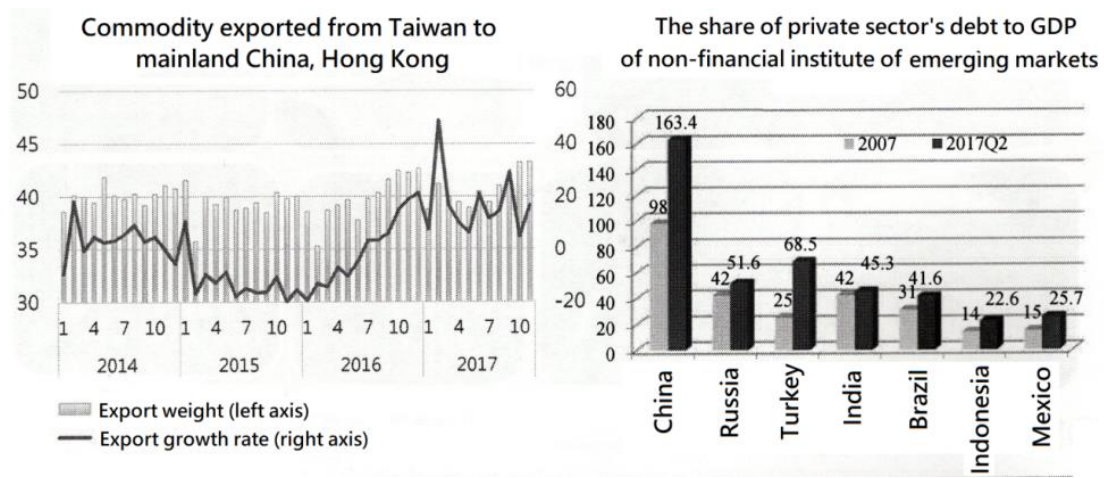

Figure 20. Taiwan's shares of commodity exported to mainland China and Hong Kong and shares of private sector's debt of non-financial institutions in emerging markets 


\subsection{The Domestic Industrial Investment Trend and the Implementation of Public Expenditure}

The capital equipment imports have shown negative growth since May 2017 (e.g., 0.65\% in November, calculated by the US dollar). Among them, the semiconductor equipment has shown a double-digit reduction since May (e.g., $-29.68 \%$ in November, calculated by the US dollar), indicating a possible change in the future investment prospects of related industries.

On July 3, 2017, the Legislative Yuan passed the "Forward-looking Infrastructure Special Regulations." Based on the estimates by DGBAS ((Directorate-general of Budget, Accounting and Statistics), its effectiveness will increase the real GDP by 470.5 billion NTD, the nominal GDP by 506.5 billion NTD. The contribution to annual real GDP growth will be $0.1 \%$. Among them, the budget allocated for the year of 2017 is 16.08 billion NTD and 92.85 billion NTD for 2018.

Finally, the possible future impact is the election process and outcome of local public service elections to be held in November 2018, namely, the so-called "2018 9-in-1 Election."

The growth rates (\%) of major capital equipment import and public expenditure in 2017 are shown in Figure 21.
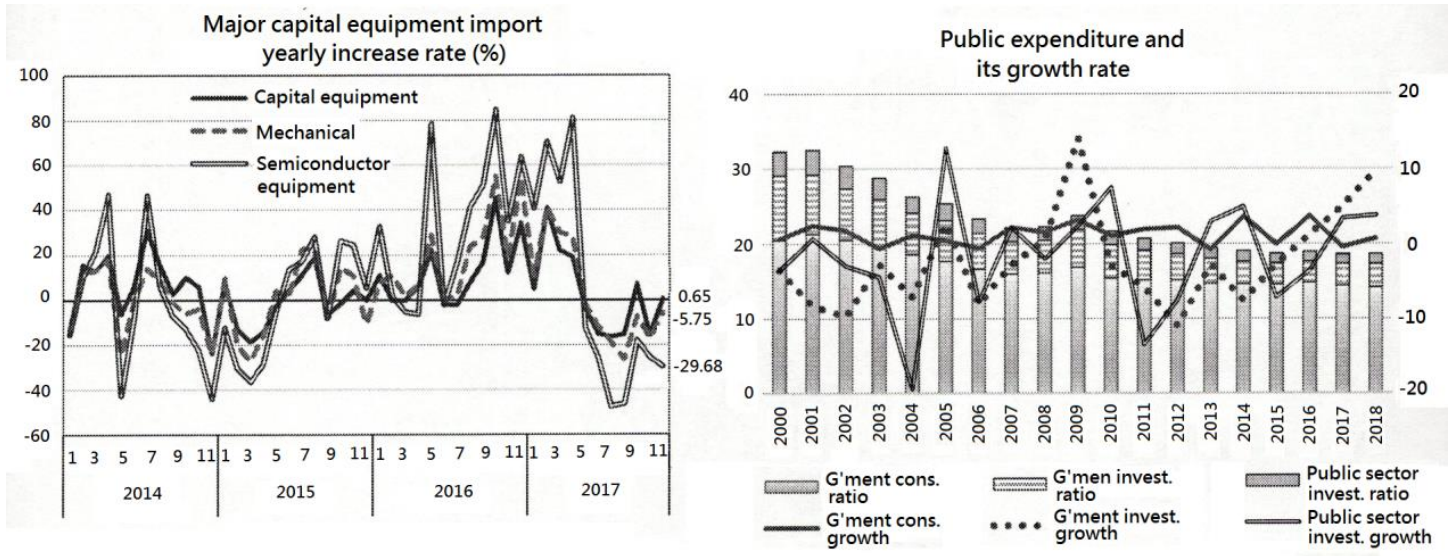

Figure 21. The annual growth rate of major capital import equipment and the public expenditure with its growth rate

Source: National Development and Reform Commission (2017).

\subsection{Ifo Experts to Assess Trump Administration's Political and Economic Impacts on the World and the United States}

The global economy forecasted in the ifo global economic cycle is optimistic for the fifth consecutive quarters. The ifo exporters are satisfactory to the status quo in the recent three quarters and optimistic about the prosperity in the future. According to the ifo survey of global economic perspectives, the ratio of the expectation of good future is down in the advanced countries (including the seven industrialized nations and the European Union), but the ratio of positive view on the status quo and future is up in the emerging markets and developing countries. Although the current situation of OPEC is declining, those who are optimistic about the future have greatly risen. They may be optimistic about the upward trend of oil prices. In addition, the Asian Four Small Dragons (Hong Kong, Singapore, South Korea and Taiwan) are not optimistic about the future. According to the ifo's survey of global economic issues, there are three major issues that most affect the economy: 1. Unequal distribution of income; 2. Lack of skilled workers; 3 . Lack of confidence in governmental economic policies.

ifo investigates Trump administration's impact on international policy. Neither the United States nor other countries' experts are optimistic about the Trump administration's international policies. The ratio of positive opinion does not exceed 5\%. In particular, more than half of respondents hold negative views on the issues of multilateral cooperation, peace and security. In terms of balancing the international trade, only $4.1 \%$ of the respondents in the United States hold a positive view. Those who think it is invalid or have negative opinions account for more than $90 \%$.

ifo investigates Trump administration's impact on the U.S. domestic policy, which was negative as a whole. Only in the business environment (37\%), the administrative efficiency (28\%) and illegal immigrant (11.1\%), the U.S. experts are more supportive, while the other issues are not optimistic. 
Is Trump tax reform in the end a radical supply-side reform or a magnetic attraction of emerging market funds? Basically, due to the implementation of TCJA, that the United States stock will be bullish in 2018 is for sure, because it can stimulate business investment, private consumption, and let oversea American companies' profits back. Among them, the business tax of $20 \%$, the overseas profit repatriation tax of $10 \%$, the individual tax (twice the standard deduction) almost are all completely reduced, while the estate tax of 2014 is $0 \%$. In addition, Goldman Sachs believes that the U.S. governmental deficit will soar to $\$ 1.2$ trillion in 2018 (only $\$ 590$ billion in 2016). People's Daily is of the opinion that the U.S. tax cuts will provoke an international tax war and kill other countries. DXY slightly rose immediately after the U.S. Senate passed the tax cuts.

\subsection{Non-Economic Factors: Geopolitical Risk}

The global geopolitical risk arising from non-economic factors in 2018 may also cause major political and economic turmoil in the world. For example,

- Americas: US congressional election in November 2018, Venezuelan political collapse, food shortage, Brazil Presidential Election in 2018, one after another nationwide strike demonstrations in South America (Brazil, Argentina);

- Europe: Irish presidential election, British local election in 2018, European refugees, Brexit influences, Talon referendum post-trends, Italian election in 2018;

- Middle East: ISIS Syrian civil war, tensions between Israelis and Arabs, Libyan presidential election in 2018;

- Africa: South Africa's political instability, the continuous decline of exchange rate of South African Rand;

- Asia: the 2018 Russian presidential election (March 18), the Russia's confrontation with Europe and the United States in Ukraine, the economic and military tensions between the United States and China, the expansion of Mainland China in the East China Sea and the South China Sea to cause military tensions in East Asia and South Asia, the military tension in the Korean Peninsula, the China-India border conflict, the 2018 South Korean regional elections (the seventh local elections), the 2018 Japan-LDP (Liberal Democratic Party) presidential election, the 2018 Taiwan local official elections and so on.

\section{Acknowledgements}

This research is not supported by any fund.

\section{References}

Accounting Office. (2017). The Ministry of Finance to discuss Taiwan's low-paid status in recent years by means of big data of finance and tax (2017.8). Retrieved from https://www.mof.gov.tw/List/Index?nodeid=285

Bureau of Labor Statistics. (2017). USA. Retrieved from https://www.bls.gov/home.htm?view_full

Department of Economic Services. (2017). Survey on manufacturing investment and operations (2017.11). Retrieved from https://www.moea.gov.tw/Mns/dos/content/ContentLink.aspx?menu_id=9433

EIA. (2017). Short-term energy outlook. November 7, 2017. Retrieved from https://www.eia.gov/outlooks/steo/report/

European commission. (2017). Autumn 2017 economic forecast. Retrieved from https://ec.europa.eu/info/business-economy-euro/economic-performance-and-forecasts/economic-forecasts/ autumn-2017-economic-forecast_en

Ifo. (2017). World economic survey (WES) IV/2017. Retrieved from https://file:///C:/Users/USER/Downloads/WES_World_IV_17.pdf

IHS Markit. (2017a). Global insight's comparative world overview. Dec. 15, 2017. Retrieved from https://ihsmarkit.com/products/global-economic-forecasts-analysis-and-data-world-economic-service.html

IHS Markit. (2017b). Global insight's comparative world overview. Nov 15, 2017. Retrieved from https://ihsmarkit.com/products/global-economic-forecasts-analysis-and-data-world-economic-service.html

IMF. (2017). World economic outlook (Oct. 2017). Retrieved from https://www.imf.org/external/pubs/ft/weo/2017/02/weodata/index.aspx

Markit economics. (2017). Retrieved from https://www.markiteconomics.com/Survey/Page.mvc/PressReleases

National Development and Reform Commission. (2017). Taiwan economic forecast and procurement manager operation outlook for 2018. Taipei, Taiwan, December 19, 2017 
OECD. (2017). Economic outlook 102. Retrieved from https://cdn.20m.es/adj/2017/11/28/3893.pdf

Taiwan Research Institute. (2017). 2018 Taiwan and major countries' economic outlook. December 14, 2017, Taipei.

WTO. (2018). World trade outlook indicator. Retrieved from https://www.wto.org/english/news_e/news17_e/wtoi_13nov17_e.pdf

Wu, T. Y. (2017). 2018 Taiwan and major countries' economic outlook. December 14, 2017, Taipei, Taiwan Research Institute.

\section{Copyrights}

Copyright for this article is retained by the author(s), with first publication rights granted to the journal.

This is an open-access article distributed under the terms and conditions of the Creative Commons Attribution license (http://creativecommons.org/licenses/by/4.0/). 